\title{
An Exploratory Study of the Impact of Top Leadership on Effectiveness of Privatization of Hospitals Through Mergers and Acquisitions in Kenya
}

\author{
Shawn Bolouki ${ }^{1} \&$ Peter Lewa ${ }^{2}$ \\ ${ }^{1}$ Aga Khan University Hospital, Nairobi, Kenya \\ ${ }^{2}$ Chandaria School of Business, United States International University (USIU) - Africa, Nairobi, Kenya \\ Correspondence: Shawn Bolouki, Chief Executive Officer, Aga Khan University Hospital, Nairobi, Kenya.
}

Received: July 5, 2018

doi:10.5430/jms.v9n3p54
Accepted: July 31, 2018

Online Published: August 5, 2018

URL: https://doi.org/10.5430/jms.v9n3p54

\begin{abstract}
This paper examines the privatization of hospitals through mergers and acquisitions (M\&A) using Kenya as the country of focus. It shows that M\&A activities are increasing in Africa and there is a history of privatization of state-owned enterprises (SOEs) / parastatals in Africa and Kenya in particular, which started in the 1990s. With the changing dynamics, increasing pressure to achieve universal health and looking at the history of mergers and acquisitions there is no doubt that this is going to become an important phenomenon in Kenya in the near future.

Privatization of hospitals, including public and not-for-profit (NFP), has been popular since 1980s in North America (U.S., Canada) and Europe (Germany, England). Privatization and M\&A activities of hospitals in other countries such as India, China, Saudi Arabia, Africa and Kenya have also increased. The reasons for these trends are industrialization of developing countries, changing lifestyles, aging populations, longer life expectancy, technological advancement, growth of the middle class, increase of non-communicable diseases (NCDs) and inefficiency of public health systems. With the changing dynamics, it would appear there is a need for African countries to expand their private sectors, and privatization of healthcare is an attractive area for private equity firms and private hospital chains. Due to growth of the economy and the middle class, higher demand for healthcare services and particularly expansion of NHIF (National Hospital Insurance Fund) coverage, privatization of hospitals makes economic sense in Kenya.

Knowledge of M\&A among top leadership is crucial in determining its success or failure. Therefore, the literature review focused on property right, transaction cost, and institutional theory. Relevant M\&A theories such as process, synergy, efficiency and disturbance theory were also reviewed.

The research philosophy, methodology and design of this study was based on exploratory, post-positivism, deduction and utilized mixed methods (qualitative and quantitative) with focus on verifying the hypothesis. The population of this research included Level 4, 5 and 6 hospitals in Kenya, totaling 268 hospitals with at least 50 beds; the sample size was 158 hospitals. Proportionate stratified random sampling methodology was used to determine the sample size of each hospital level (Level 4, 137 hospitals; Level 5, 14 hospitals; and Level 6, 7 hospitals).

The hypothesis that there is no relationship between top leadership (X) and the effectiveness of privatization of hospitals (Y) through M\&A was tested and there was a strong and positive relationship between the dependent and independent variables $(\mathrm{r}=0.821)$, and the regression model was found to be reliable. The null hypothesis was rejected because of the results of the T-test $\left(\beta_{1}=0.925, t=9.757, p<0.005\right)$.

It is recommended that similar studies be conducted in East and South Africa to enable researchers to perform comparative analyses in order to improve the body of knowledge.
\end{abstract}

Keywords: top leadership, effectiveness, privatization, merger and acquisition

\section{Introduction}

Mergers and acquisitions (M\&As) have been a subject of interest over the past 30 years: they are a multidisciplinary, popular form of corporate growth that encompasses strategic, financial, operational, behavioural, and cross-cultural management challenges; they are used as a response to changing economic conditions, and as competitive strategy. If 
ignored, it can have negative consequences for companies since M\&A activities have a clustering pattern that is characterized as waves (Sudarsanam 2003, 2005; Bruner, 2004; Cartwright \& Schoenberg, 2006).

The first wave of M\&A was a horizontal consolidation from 1897 to 1904. The second wave was a horizontal and vertical consolidation from 1916 to 1929 and resulted in the passing of Clayton Antitrust Act in the United States. The third wave, from 1965 to 1969 , is described as a conglomeration. The fourth wave, known as the retrenchment era, ran from 1981 to 1990; it is marked by the rise of hostile takeovers. The fifth wave, from 1992 to 1999 , is described as the strategic management era and there were a record number of transactions because of globalization; it ended in 2002. The sixth wave started in 2003 and was considered as the rebirth of the leveraged buyout due to low interest rates, globalization, and high commodity prices - it ended during the 2008 stock market crash. The year 2011 was the beginning of the seventh wave of M\&A and it was characterized by the rise of Brazil, Russia, India and China (BRIC) and more recently, South Africa (DePamphilis, 2015; Camaya Partners, 2014).

The number of M\&A transactions in Africa grew from 3 in 1996 to 29 in 2010. The total number of transactions in Africa was $1 \%$ of the global transactions in 1996 with a value of US\$2 billion, and grew significantly from 2003 to 2007 but declined thereafter, possibly due to the financial crisis of 2008. South Africa was number one and Kenya ranked number eight in deal-making among the top ten target African countries that included Egypt, Nigeria, Morocco, Mauritius, Zimbabwe, Namibia, Tunisia and Mozambique (Holthausen \& Zmijewski, 2014; Ellis, Lamont, Reus \& Faifman, 2015).

The number of privatization transactions in Africa was 2,270 in the 1990s. Mozambique, Zambia and Tanzania led the pack with Kenya ranking fourth, and the major privatization activities were in manufacturing and industry, agriculture, service and real estate sectors. Governments retained $46 \%$ of energy and $42 \%$ of telecoms shares after privatization and the average share of equity of government was $10 \%$ after privatization (Nellis, 2005). Governments retained shares in divested privatized companies under the pretense of protecting public interest with the intention to sell the retained shares at a higher price at a later date when the value had increased. Privatization of hospitals was a minimal affair and was achieved in Kenya through the opening of private wings in major government hospitals.

In Africa, the challenge is how to privatize SOEs in a transparent and corruption-free manner. Although all methods are prone to manipulation, Nellis (2005) argues that the sale of shares through a public offering is more transparent.

State owned enterprises (SOEs) in African countries provide poor services and lose money hence the intervention by the International Monetary Fund (IMF) in the early 1990s that brought about Structural Adjustment Programs to advocate for financial discipline and market-oriented reforms.

It has been argued that there is a need for sub-Saharan African countries to expand their private sectors and create more dynamic economies. Muindi (1992) states that the Kenyan government directly participated in production and trade after independence in 1963. In the 1970s, the government realized that its involvement had grown beyond the original intent; therefore, in 1979 it formed the Parastatal Advisory Committee. In 1982, the Working Committee on Public Expenditure released a report which identified deficiencies in the financial and economic performance of Public Enterprises (PEs) and this report set the stage for change.

Privatization involves divestiture, transfer of a function, activities and assets from the public sector to the private sector (Klos, 2000). There are about 240 Kenyan PEs with government ownership, 33 of them have been classified as strategic institutions since they provide essential services such as healthcare and environmental protection or are vital for national security. The remaining 207 PEs were classified as non-strategic companies and were included in the Kenyan government privatization program. According to Privatization Commission of Kenya (2016) website, most of the non-strategic assets had been either fully or partially privatized by 2002 .

The Kenyan government privatized a number of key enterprises under the Economic Recovery Strategy for Wealth and Employment Creation (2003-2007), which included the following companies: Kenya Electricity Generating Company (KENGEN); the concession of Kenya Railway operations; Mumias Sugar Company; Kenya Reinsurance Corporation; and sale of $51 \%$ of Telecom Kenya. These transactions generated Ksh.80 billion (US\$800 million) for the government. The following firms are currently seeking privatization in Kenya: Agrochemical and Food Company Limited; Kenya Meat Commission; New Kenya Cooperative Creameries Ltd; Kenya Wine Agencies; Development Bank of Kenya; National Bank of Kenya Ltd; Tourism Finance Corporation; Kenya Ports Authority; Consolidated Bank of Kenya Ltd; Kenya Pipeline Company Ltd; East African Portland Cement Company; and five sugar companies (Privatization Commission of Kenya, 2016; Reuters, 2015). 


\subsection{Healthcare Financing}

Africa's population is expected to grow to 2 billion people by 2050, necessitating the need for greater health care and additional social expenditure, and this shift will increase demand for healthcare. Kenya experienced an 18.6\% population growth from 2008 to 2015 and spent less than 5\% of its annual gross domestic product (GDP) on health care (KPMG, 2011; Canning, Raja, \& Yazbeck, 2015).

Healthcare financing means raising or collecting funds to pay for the operation of a healthcare system and the intent is to collect revenue from a variety of sources, such as public or private sources and pool funds, and spread risks across larger population groups (World Health Organization, 2000; Mills \& Ranson, 2001; Carrin \& James, 2005). Pooled healthcare financing arrangements reduce risk and are achieved by subscribing to an insurance policy or by being a citizen eligible to receive publicly provided healthcare. Risk pooling has two redistributive impacts cross-subsidy from the healthy to the sick and differential contribution transfer from the rich to the poor (World Health Organization, 2000; Fan \& Savedoff, 2014). Approaches to risk pooling are: no risk pooling; a fragmented risk pool; an integrated risk pool; and a unitary risk pool. Progressive integration of risk pooling reduces the risk and minimizes the medical loss ratio under a unitary risk pool (Smith \& Witter, 2004).

Social health insurance (SHI) was introduced in Kenya in 1960, Namibia in 1980 and Burundi in 1984 (Witter, Ensor, Towett \& Thompson, 2000). Chuma and Okungu (2011) argue that Kenya has not had a consistent health policy for its population. Table 1.1 summarizes healthcare financing in Kenya since independence.

Table 1. Development of healthcare financing policies in Kenya

\begin{tabular}{ll}
\hline Years & Policy \\
\hline $\begin{array}{l}\text { Colonial } \\
\text { period }\end{array}$ & User in all public facilities. \\
1963-1965 & $\begin{array}{l}\text { User fees initially introduced continued to exist for two } \\
\text { years after independence. }\end{array}$ \\
$\begin{array}{l}\text { User fees removed at all public health facilities. Health } \\
\text { services provided for free and funded predominantly } \\
\text { through tax revenue. }\end{array}$
\end{tabular}

1989 User fees introduced in all levels of care.

User fees suspended in all public health facilities. Waivers 1990 and exemptions put in place to protect the poor and vulnerable. Failure linked to poor policy design and implementation.

User fees were re-introduced in 1991, through a phased implementation approach starting from the hospital level. Children under five, special conditions/services like immunization and tuberculosis were exempted from payment. User fees continued to exist in Kenya at all levels of care.

User fees abolished at dispensaries and health centers (the lowest level of care), and instead a registration fee of Kenya

2004 shillings 10 (US\$ 0.1 to 0.2 ) and 20 respectively was introduced. Children under five, the poor, special conditions/services like malaria and tuberculosis were exempted from payment.

2007 All fees for deliveries at public health facilities were abolished.

A health sector services fund (HSSF) that compensates

2010 facilities for lost revenue associated with user fee removal introduced. Dispensaries and health centres receive funds directly into their bank accounts from the Treasury.

\section{Equity impacts \\ Discriminative policy against indigenous Kenyans, imposed by colonial government. \\ Negative impact of affordability and utilization of health care services. \\ Potential for equity provided there are mechanisms to ensure that the poor benefit from the tax funded system. \\ Negative impact on demand for health care especially among the poorest population: decreased utilization including essential services like immunization.}

Increase in utilization patterns, confirming previous reports that user fees are a barrier to access.

User fees a major barrier to access, high out-of-pocket payment, catastrophic impacts, and negative implications for equity.

Utilization increased by $70 \%$, which was not sustained although general utilization was $30 \%$ higher than before user fee removal. Adherence to the policy has been low due to cash shortages.

No data on the extent to which policy was implemented and no evaluation has taken place.

Possible positive impacts on adherence to fee removal policy and equity

Source: Chuma \& Okungu (2011) 
Table 1 shows that the policies set by the Kenyan government have not been consistent in regard to healthcare financing since independence.

World Bank (2012) report defines total healthcare expenditure as a percentage of gross domestic product (GDP) and further as the sum of public and private health expenditure that covers the provision of preventive health services, curative health services, family planning activities, nutrition and emergency aid designated for health. It does not include any provision for water and sanitation. Healthcare expenditure per capita is the sum of public and private health expenditures as a ratio of total population for the provision of health services (The World Bank, 2012).

In April 2001, the heads of state of the Organization of African Unity (OAU) pledged to allocate at least 15\% of their annual budget for improving the health sector (Organization of African Unity, 2001) and this commitment was reaffirmed in 2003 (African Union, 2003). Four African countries - Zambia, Togo, Rwanda and Burkina Faso - have achieved this target. In contrast, Kenya's expenditure on health dropped from more than $10 \%$ in 2000 to approximately 7\% in 2009 (Sambo, Kirigia \& Orem, 2013). This was allegedly due to lack of healthcare financing.

The World Health Organization (WHO) Commission for Macro-economics and Health estimates that governments must spend a minimum of US\$34 per person every year in order to provide an essential package of public health intervention that includes promotive, preventive, curative and rehabilitative care (Kirigia, Preker, Carrin, Mwikisa \& Diarra-Nama, 2006). Table 2 presents healthcare expenditure as a percentage of GDP and per capita from 2010 to 2012 for the Middle East, Africa and selected countries (World Bank, 2012).

Table 2. Healthcare expenditure by region and country

\begin{tabular}{lllllll}
\hline Middle East & \multicolumn{3}{l}{ Expenditure percentage of GDP } & \multicolumn{3}{l}{ Expenditure per capita } \\
& $\mathbf{2 0 1 0}$ & $\mathbf{2 0 1 1}$ & $\mathbf{2 0 1 2}$ & $\mathbf{2 0 1 0}$ & $\mathbf{2 0 1 1}$ & $\mathbf{2 0 1 2}$ \\
\hline Israel & $7.6 \%$ & $7.6 \%$ & $7.5 \%$ & $\$ 2,165$ & $\$ 2,373$ & $\$ 2,289$ \\
Jordan & $8.5 \%$ & $8.8 \%$ & $9.8 \%$ & $\$ 361$ & $\$ 386$ & $\$ 388$ \\
UAE & $3.2 \%$ & $3.1 \%$ & $2.8 \%$ & $\$ 1,283$ & $\$ 1,375$ & $\$ 1,343$ \\
Africa & Expenditure percentage of GDP & Expenditure per capita & \\
& $\mathbf{2 0 1 0}$ & $\mathbf{2 0 1 1}$ & $\mathbf{2 0 1 2}$ & $\mathbf{2 0 1 0}$ & $\mathbf{2 0 1 1}$ & $\mathbf{2 0 1 2}$ \\
Kenya & $\mathbf{4 . 4 \%}$ & $\mathbf{4 . 4 \%}$ & $\mathbf{4 . 7 \%}$ & $\mathbf{\$ 3 5}$ & $\mathbf{\$ 3 5}$ & $\mathbf{\$ 4 5}$ \\
Tanzania & $7.2 \%$ & $7.4 \%$ & $7.0 \%$ & $\$ 37$ & $\$ 38$ & $\$ 41$ \\
Uganda & $9.2 \%$ & $9.3 \%$ & $8.0 \%$ & $\$ 43$ & $\$ 41$ & $\$ 44$ \\
\hline
\end{tabular}

In Kenya, healthcare expenditure as a percentage of GDP increased by $28.6 \%$ from 2010 to 2012 (Sambo, Kirigia \& Orem, 2013). The reasons for escalations in healthcare costs are industrialization of developing countries; change of lifestyles; ageing populations; longer life expectancy; rapid technological advancements in medicine; the development of new drugs; and the prevalence of non-communicable diseases (NCDs) such as cardiac diseases, hypertension, diabetes and other chronic diseases. Increase in expenditure for healthcare will impact government policy concerning the provision of healthcare and the possibility of privatization of public hospitals.

\subsection{Privatization of Hospitals}

Numerous activities on privatization and M\&A of healthcare facilities are documented in the developed world. The majority of public hospitals are inefficient and non-responsive to the needs of the population; therefore the change of status of hospitals from government-owned to not-for-profit has shown to improve the efficiency of public hospitals by transferring assets from public to private ownership. Not-for-profit hospitals have also been converted to private for-profit hospitals. In the U.S., a total of 1,653 hospitals were consolidated between 1980 and 2015 (Irving Levin Associates, 2012; Villa \& Kane, 2013; Kaufman-Hall, 2015). Privatization of healthcare is ongoing in the U.S., Canada, Germany, India, China, Saudi Arabia and Africa (Himmelstein \& Woolhandler, 2008; Martin \& Dhalla, 2010; Doherty, 2011; Sinha, 2012; DeNoble, 2013; Villa \& Kane, 2013; Action Platform Health and Solidarity, 2014; Hail, 2016). It is anticipated that these activities will increase in Africa and in Kenya specifically due to future demand for healthcare, a trend that occurs as a consequence generally. The New Public Management (NPM) orthodoxy advocates for a more limited and efficient government for delivery of public goods through re-engineering, 
deregulation, decentralization, performance management, and privatization (Battaglio \& Legge, 2008). This thinking has been embraced in Kenya.

The African Health Fund has invested a total of US\$6.5 million in the Nairobi Women's Hospital; the Avenue Group has partnered with Abraaj, a private equity firm; and Kenya is a target for expansion by equity firms (Avenue Group Profile, 2016; Collins, 2013; Mohandas, 2016; Thomas, 2016). This can be considered as a first step of involvement of equity firms in the development of for-profit health systems in Kenya, and the International Finance Corporation (IFC) identified the health sector as one of the top 5 promising investment opportunities in Africa (Doherty, 2011).

A study of privatization of hospitals in Kenya through M\&A is optimal at the moment since Kenya is an attractive target for cross border acquisitions (CBA) by private equity funds due to its projected economic growth, increased demand for healthcare services, and expansion of the National Hospital Insurance Fund (NHIF).

\subsection{Motivation for Merger and Acquisition}

M\&As create synergies, expand corporate operations and markets, eliminate inefficiencies, improve productivity, profit and economies of scale that ultimately leads to better financial performance and competitive advantage. They create shareholder gains, promote the dissemination of know-how, foster research and development opportunities, expand internal capital markets and increase diversification. They also raise entry barriers, spread portfolios and obtain multimarket contacts (Motis, 2007; Chand, 2009).

There are four motivation categories for M\&A: exploitation, exploration, statis and survival (Angwin, 2007) and the main motives are strategic (synergy), managerial, financial and third party motives (Motis, 2007; Angwin, 2007; Riley, 2012; Arnold, 2013).

\subsection{Privatization, Merger and Acquisition Process}

Privatization is the deliberate sale of state-owned enterprises or assets by government. It is the process of transferring assets from public to private ownership and control and the liquidation of the organization previously using those resources (Battaglio \& Slegge, 2008; Klos, 2000; Megginson \& Netter, 2001). In its most basic form, a merger and acquisition takes place when one firm acquires another firm. There are typically two parties involved, a buyer (the acquirer or bidder) and a seller or (target firm), and the successful transaction is called a takeover. Takeovers can occur by acquisition, proxy contests, going-private transactions, and can encompass a broader set of activities other than acquisitions (Ross, Westerfield \& Jaffe, 2010; Berk, DeMarzo \& Harford, 2013). The acquisition of another firm can follow one of the following three basic forms: merger or consolidation, acquisition of stock, and acquisition of assets. A merger refers to the absorption of one company by another company (acquiring company) that then assumes control of all assets and liabilities. A consolidation is the same as a merger except that a new company is created and stockholders must approve the transaction.

A merger or acquisition can be classified as follows: horizontal, when both acquirer (buyer) and acquired (seller) are in the same industry; vertical, when the firms are in different steps of the production process; or conglomerate, where the firms are not related to each other (Finkler, Ward \& Baker, 2007; Chartered Financial Analyst Institute, 2013). The process of mergers and acquisitions consists of 6 main stages: corporate strategy; pre-merger; organizing for acquisitions; deal structuring (affiliation, joint venture, joint operating agreement, merger, acquisition); financial due diligence; non-financial due diligence; post-acquisition integration, and post-acquisition audit such as balanced scorecard and operational audit (Evans, 2000; Dixon, Hughes \& Goodman, 2013; Ruppert, 2009; Kaplan \& Norton, 1996).

\subsection{Statement of the Problem}

Nellis (2005) states there is a need for sub-Saharan African countries to expand their private sector. Privatization of healthcare has been ongoing in the U.S. since the 1980s and studies by Shah and Mohanty (2010), Doherty (2011), Sinha (2012), Villa and Kane (2013), DeNoble (2013), Action Platform Health and Solidarity (2014) and Hail (2016) show that this trend is continuing in the U.S., Germany, India, China, Saudi Arabia and Africa/Kenya.

Discussions with key informants in Kenya and in the Kenyan financial industry indicate that the activities of private equity funds in Kenya are increasing and the country is a target for expansion of for-profit hospital systems from abroad according to recent articles by Mohandas (2016), Thomas (2016), and Business Daily (2016). The fastest way for a health system or equity fund to expand is to acquire existing public and NFP hospitals. There is pressure on central and county governments to improve the delivery of healthcare and one approach is to use New Public Management (NPM) strategy and privatize public hospitals. Studies in Africa and in particular Kenya regarding privatization are scarce or nonexistent. A review of existing studies indicates that they are more focused on banking 
and other sectors such as consumer products, pharmaceuticals, tourism, agriculture, insurance and mining. There is also a conceptual knowledge gap among healthcare leaders in Kenya concerning hospital privatization, mergers and acquisitions. Therefore, the intent of this research was to determine the effectiveness of hospital privatization through merger and acquisition in Kenya by exploring the following hypothesis.

$\mathrm{H}_{0}$ : There is no relationship between top leadership and the effectiveness of hospitals privatization through merger and acquisition.

\section{Literature Review}

"Theory emphasizes the nature of causal relationships, identifies what comes first and timing of such events, and it also examines underlying processes in order to understand the systematic reasons for a particular occurrence or nonoccurrence" (Kaplan, 1964; Merton, 1967; Sutton and Staw, 1995).

A theoretical framework is a structure that identifies and describes the major theories that organize research or a study and it is used to hypothesize, understand or give meaning to the relationships among the elements that influence, affect or predict the events or outcomes specified in the research (Smith, 2004; Kombo and Tomp, 2009). Figure 1 depicts the theoretical framework of this research.

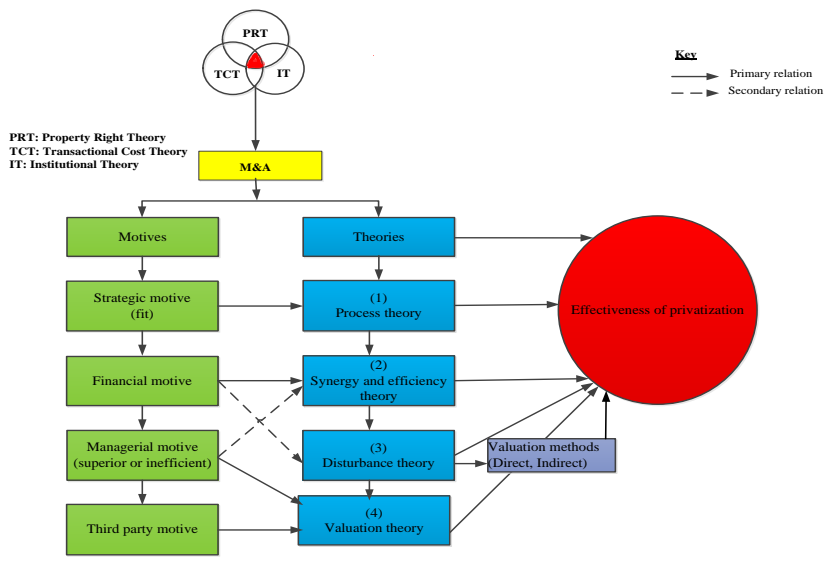

Figure 1. Theoretical framework for privatization through mergers and acquisitions

Source: Author (2016)

\subsection{Property Rights Theory}

Kim and Mahoney (2005) state that the origin of property rights theory (PRT) within the context of strategic planning can be traced to Coase (1937). Early property rights literature was developed by the following scholars: "Alchian (1965, 1969), Demsetz (1964, 1966, 1967), Cheung (1968, 1969, 1970), and Furubotn and Pejovich (1972, 1973, 1974)" (as cited in Kim \& Mahoney, 2005). Modern property rights theory started with the work of Grossman and Hart in 1986 and Hart and Moore in 1990 (GHM Model).

Property rights are an owner's right to use the benefits of his / her assets, exclude others and be able to transfer these rights to others. They include a bundle of decision rights involving the asset such as the right to access, the right of exclusion, the right to transfer and the right to profit (Segal \& Whinston, 2010). Alchian and Demsetz (1978, p.16), state "capitalism relies heavily on markets and private property rights to resolve conflicts over use of scarce resources". In property rights what is owned are rights to use resources and socially recognized rights of action. However, these rights of use of resources might be divided among several parties and those partitions of rights can be aggregated into bundles of property rights. According to Libecap (1989) property rights are: rights to use, to earn income from and to transfer or exchange the assets and resources. Therefore, property rights have multiple dimensions with important economic implications when different people hold partitions of rights to a single resource.

Grossman and Hart (1986) assert that a firm is composed of assets such as machinery and inventories that it owns or has control over, and ownership means the power to exercise control. This control belongs to the shareholders of the corporation and it can be delegated to the governing board and management. In addition, they explain that 
contractual rights can be of two types: specific and residual. A party may buy another party's asset when it is too costly for it to specify a long list of specific rights that it wants to have over the other party's rights. This can lead to horizontal or vertical integration, which is a cheaper option, and ownership is the outright purchase of residual rights of control.

The GHM model asks the strategic question of who should own the assets of a firm. It states that residual control rights in relation to specific assets must be concentrated in one contracting party and rights to residual control over assets and residual return are associated with asset ownership. Classical property rights theory defines ownership as residual rights to income. Residual rights of control are not divisible; however, residual rights to income are (Kim \& Mahoney, 2005). Therefore, there is a need for third party enforcement of contractual rights, a demand that is met by political institutions that play a positive role in specifying and enforcing property rights since transactions have become more specialized and complex in nature (DiMaggio \& Powell, 1991).

\subsection{Transaction Cost Theory}

The work of Coase, Alchian, Demsetz and Williamson formed the foundation of transaction cost theory (TCT) (Kim \& Mahoney, 2005). Transaction cost theory has applications in the fields of social sciences and strategic management and is important for analysis of firms in the areas of organizational studies, strategic management, studying vertical integration, or acquisition decision making (Carroll, Spiller \& Teece, 1999; Martins et al., 2010). Transaction cost is the general overhead cost of maintaining a system of property rights under conditions of growing specialization and complex division of labor. It is "the cost of exchanging ownership titles" (North, 1984; Demsetz, 1988, p.64; Allen, 1999).

The optimal size of a firm is defined as the number of internally organized transactions and Coase (1937) argues that every transaction organized within a firm results in additional internal costs and the entrepreneur's capability of making the best use of production factors decreases. Consequently, a firm will expand until the cost of additional transactions within the firm becomes equal to the cost of the same transaction in the market or the same cost of organizing it within another firm (Coase, 1937; Ruester, 2010).

According to Williamson (1993, p. 16) the basic unit of analysis of TCT is "the transaction and it occurs when a good or service is traded across a technologically separable interface". Williamson suggests that transaction costs include two costs: direct cost and opportunity cost. His microanalysis framework is based on the assumptions of human behavior, opportunism, and of asset specificity (Williamson, 1993; Rindfleisch \& Heide, 1997). The principal attributes of transactions are frequency, uncertainty, and asset specificity. Uncertainty is a necessary condition for asset specificity which refers to the degree with which an asset can be redeployed to alternative use without sacrificing productive value. There are six types of asset specificities: site asset; physical asset; dedicated asset; human asset; intangible asset; and temporal asset. Integration, asset specificity and uncertainty are important drivers of vertical integration (Ruester, 2010; Klein \& Shefanski, 1994).

Transaction cost theory states that there are costs for conducting transactions through the market and they can be reduced through mechanisms other than market. TCT shows up in research papers that deal with corporate strategy such as vertical integration decisions, horizontal and vertical diversification, mergers and acquisitions, hybrid governance, and make or buy strategy (Coase, 1937; Williamson, 1975; Klein \& Shefanski, 1994; Martins et al., 2010).

\subsection{Institutional Theory}

The field of institutional theory is composed of old institutionalism tracing back to Philip Selzish in 1949 and new institutionalism tracing back to John Meyers in 1977. "Both theories emphasize the relationship between environments and organizations, and promise to reveal aspects of reality that are inconsistent with organizations' account" (DiMaggio \& Powell, 1991, p. 12).

An institution can be formal rules and organization or informal rules and norms (Della Porta \& Keating, 2008). Institutional theory is a popular theoretical foundation for exploring a wide variety of topics such as organizational theory, political science, and institutional economics. It is concerned with regulatory, social, and cultural influences that promote survival and legitimacy of an organization rather than focusing on efficiency seeking behavior (Bruton, Ahlstrom \& Li, 2010; Roy, 1997; Oliver, 1991) and it is composed of rules, myths, and beliefs that combine together to form a common social reality. It views the social world to be comprised of institutions, enduring rules, practices, and structures that establish conditions of action (Lawrence \& Shadnam, 2008).

Punctuated equilibrium means that institutions remain stable until there is an exogenous shock (Thelen \& Steinmo, 1992). Krasner (as cited in Thoenig, 2007) states that institutions respond to changes in the power balance within 
society and Scott (2007, p. 423) summarized institutional forces in three categories, "the regulatory pillar, the normative, and the cognitive pillar". DiMaggio and Powell (1983) identified three mechanisms of institutional isomorphic changes - coercive, mimetic, and normative isomorphism. Scott (2001) asserts that institutions can weaken and disappear through deinstitutionalization. It causes weakening and disappearance of one set of beliefs and replaces them with new ones. The three major sources of deinstitutionalization are functional, political, and social change (Oliver, 1992; Dacin, Goodstein \& Scott, 2002).

Institutional theory focuses on exogenous forces that lead to isomorphic changes and deinstitutionalization that might lead to M\&A and this theory assumes that organizations require social acceptability, credibility, and legitimacy in addition to resources such as financial, human, and technical information in order to survive and thrive in their environment (Krishnan, Joshi, \& Krishnan, 2004). Consequently, since institutions' environments change as a result of regulatory, macroeconomic, and international events it is possible that the institutional norms motivate firms to merge with or acquire other institutions in order to be in agreement with prevailing norms of their business environment (Carbonara \& Caiazza, 2009).

Carbonara and Caiazza (2009) argue that different theoretical perspectives identify determinants of M\&A that is considered a strategic decision and the field of strategic management borrows from other disciplines such as property rights, transaction cost, and institutional theory.

\subsection{Process Theory}

Process theory is a recently developed field that describes strategic decisions, such as mergers, as outcomes of several processes rather than comprehensive rational systems of choice considering the following influences: individuals are limited in their information processing capabilities, which leads to less than optimal outcomes; organizations tend to employ procedures that have been successful in the past and, as a result, are generally risk averse in trying out new pathways for new problems; and the decision process is an outcome of an organization's internal and external political games (Simon, 1957; Cyert \& March, 1963; Gaddis, 1987; Trautwein, 1990).

The decision process itself may also be driven by personalities of the deal makers and by cultural differences of the organizations (Sales \& Mirvis, 1984). Process theory is applicable to M\&A because limited information is available during the process, leadership relies on past experience and the organization's political situation will impact decision making.

\subsection{Synergy and Efficiency Theory}

Synergies occur when people collaborate successfully to achieve breakthroughs in thinking and action, which in turn combines the knowledge, skills, and resources of the group and mutual benefit stems from the complementary combination and use of resources (McCutchen \& Swamidass, 2004; Lasker \& Weiss, 2003). Synergy theory seeks to explain strategic alliances as symbiotic relationships between buyers and sellers (Hamilton, 1990; Pisano, 1991; Shan \& Visudtibhan, 1990). Motivations for synergistic behaviors include risk reduction, pooling of resources, achieving economies of scale, production rationalization, and the convergence of technology (Shan \& Visudtibhan, 1990).

Efficiency theory seeks to explain mergers as planned activities that lead to synergies such as financial synergies to lower cost of capital; operational synergies to reduce the cost of doing business or to enable new product or service offerings; and managerial synergies to create leaner management structures thereby enhancing the target's performance (Trautwein, 1990). Financial synergies, rather than operational synergies, are more likely to be achieved through mergers (Chatterjee, 1986); the gains, however, are more often realized by the target's shareholders (Trautwein, 1990). Porter (1987) and Ravenscraft and Scherer (1987) further show that acquiring companies, based on their financial performance (i.e., financial statements rather than stock value), are in weaker positions than acquired companies. Critics also argue that operational and managerial benefits, while often cited as reasons for mergers, are seldom realized (Trautwein, 1990; Porter, 1987).

Efficiency theory has not yielded conclusive data on the synergies that mergers supposedly seek to create or strengthen (Rothman, 1988; Smith \& Sandler, 1988). Synergy and efficiency theories are appropriate for the study of M\&A since the objective is wealth maximization for shareholders through the improvement of financial, situational, or managerial expertise.

\subsection{Disturbance Theory}

Disturbance theory, in the context of merger waves, is described by Gort (1969) as outcomes stemming from 'economic disturbances' (Trautwein, 1990). As a result, individual expectations change - in particular, valuation of 
assets by both owners and non-owners increases - and overall uncertainty surrounding the merger increases (Trautwein, 1990). Disturbance theory suggests that a merger wave, i.e. an increase in the frequency of mergers, would then ensue. Disturbance theory has not gained widespread acceptance and resilience because it lacks rigorous academic proof. Exogenous forces can cause disturbances in macro- and micro-economic, internal and external organizational environments or can result in regulatory requirement changes leading to consideration of M\&A by organizations.

\subsection{Results of Empirical Studies on the Effect of Top Leadership}

State-owned enterprises (SOEs) have ambiguous objectives that focus on maximizing the public interest which makes it difficult for citizens (stakeholders) to hold top leadership and ministers (agents) accountable. The reason for this is to diffuse ownership, which makes it difficult to create managers' incentives tied to returns from managers' decisions (Shleifer, 1998).

The firm's resources that are primary determinants of its fair market value during M\&A and two theoretical perspectives to value a firm are the market-based view approach (MBV) and the resource-based view (RBV) (Porter, 1979; Wernerfelt, 1984; Barney, 1991; Barney \& Hesterly, 1996). Knowledge of MBV and RBV among top leadership are beneficial during the privatization, M\&A for determining the true value of a firm. Top leadership with the ability to manage in a competitive environment (knowledge) represents an intangible value-creating resource for the company as per RBV theory. Therefore, a competitive capability is vital for success that is associated with entrepreneurial ability, which is the ability to be innovative, make decisions that have difficult objectives and uncertain outcomes, and that have significant risks and consequences (Makhija, 2003).

Two types of leaders are leaders who are task-oriented ("Theory E") and leaders who are more person-oriented ("Theory O"). This has an effect on how they implement and manage change (Beer \& Nohria, 2000; Battilana, Gilmartin, Sengal, Claire-Pache, \& Alexander, 2010). A task-oriented leader must build coalitions in order to mobilize needed resources emphasizing on communicating activities, compared to a person-oriented leader who is good at communicating. Therefore, top leadership with advanced management education places less emphasis on mobilizing tasks of change implementation, which might affect managers' effectiveness as both skills are needed during M\&A. There is a need for ongoing communication by top leadership for successful M\&A and much of this happens at an early stage, targeting customers, employees, partners, investors, and media (Renyen \& Decamara, 2004).

The philosophy and objectives of an organization can be determined by privatization and incorporation. However, this doesn't take into account certain considerations regarding professional management orientation towards efficiency and the generation of surplus (Shah \& Mohanty, 2010). One of the main changes introduced in privatization at the firm level is governance arrangement because it has an impact on the top leadership of the firm. However, a new governance mechanism is dependent upon government residual ownership and the type of private capital provided by management and employees, local business groups or multinational companies (Ramamurti, 2000).

Inefficient management (leadership) and structures within a hospital can be removed after M\&A based on the restructuring hypothesis. Privatization of SOEs / hospitals can lead to a change of top leadership which can act as a major catalyst in the internal change process (Jarrell, Brickley, \& Netter, 1988; Cuervo \& Villalonga, 2000). Parrino, College and Harris (1999) and Castanias and Helfat (1991) suggest that the simplest way to break resistance is to change the managers since a new management team might bring different capabilities and resources that were not available to the SOEs and these skills are different from skill sets of state-owned management. According to Shen \& Lin (2009), top leadership turnover has a positive impact on return of assets (ROA) and earning per share (EPS) when the firm's performance is below target and it has a negative impact when the performance is above target. This explains why privatization improves the quality of corporate governance and makes poor performing top leadership (management) accountable for financial performance (Shleifer \& Vishny, 1997).

Hellgren, Sverke, Falkenberg, and Baraldi (2005) conducted cross-sectional studies of healthcare organizations and found that the type of organization and ownership may be related to employees' work environment and attitude. Leadership, justice, and trust in the management affected employees' environment and attitude. These factors have been rated more positively in hospitals that run as for-profit (FP) as well as not-for-profit (NFP) compared to public hospitals. Patel, Trivedki, Nayak and Patel (2010) and Pinto and Udwadia (2010) state that $62 \%$ of the households in India preferred private healthcare facilities. The reasons were low faith in management and government doctors (top leadership). 
The leadership and management of privatized firms must have an understanding of the three dimensions of agreement during privatization and M\&A process and its impact on performance. These three dimensions of agreements are perceived agreement, actual agreement, and accuracy of the agreement. Individual and group behavioral factors such as individual skills, biases, group dynamics, conflict, cohesion, and intergroup factors will influence the levels of agreement reached by leadership and management. Understanding the agreement by top leadership will help with integration and creation of synergy, reduction of complexity and stress during privatization through M\&A (Shanley \& Correa, 1992).

Nemanich and Keller (2007) conducted a study to provide new evidence on transformational leadership and subordinate performance, job satisfaction and merger and acquisition acceptance. They found that transformational leadership had a positive relationship with the acceptance of an acquisition as well as improved performance, job satisfaction and clarity of goals and objectives. However, one shortcoming was that this study could not be generalized. Bratianu and Anagnoste (2011) studied the role of transformational leadership in M\&As in emerging economies. Their approach included qualitative and quantitative approaches consisting of seven determinants: values, vision, optimism, innovation and change, trust, motivation, and emotional intelligence. The results identified the following factors to be important: the vision that a leader has and his / her role as a change agent; a leader's relationship with the group; trust; moral and ethical decision-making in collaboration with employees; optimism; motivation; and emotional intelligence in order to accomplish a successful M\&A.

Butler, Perryman and Ranft (2012) examined the effect of top leadership turnover on a firm's performance from a resource-based view (RBV). They investigated ROA, ROE, Tobin's Q, and CAR (Capital Adequacy Ratio) and found that management turnover impacted performance from a RBV. One important finding was the role of human resource managers in coordinating with the target company for successful performance, integration, and for how long top management should be retained. Junni and Sarala (2014) studied the role of leadership in M\&A and found that the majority of studies focus on M\&A integration. However, there is a lack of knowledge regarding M\&A leadership and how it influences M\&A outcomes. M\&A leadership behaviors that dominate research studies are culture, identity, ethics, target firm leadership behavior, traits, power, and politics.

\subsection{Result of Empirical Studies on Effectiveness of Privatization}

Concern over increases in government expenditure has led to privatization or denationalization that started in the 1960s by the Adenauer government in Germany and the Thatcher government in the 1980s in England. Table 3 shows government expenditures of some selected countries from 1913 to 1990. Ramamurti (2000) states that only 10\% of the SOEs assets in the developing countries and 30\%-40\% of SOEs assets in the transitional economies (TE) had been privatized as of 1996 . He considers privatization at three levels, namely firm, industry, and country and states that the combined effect of these reforms changes the performance of firms and M\&A is not a one-shot event but a process that evolves. The empirical evidence demonstrates that the quality of services provided by private firms might be equivalent or better than services provided by public institutions (Gerber, Hall, \& Hines, 2004).

Table 3. Government expenditure from 1913 to 1990 as percentage of GDP

\begin{tabular}{lllll}
\hline COUNTRY & $\mathbf{1 9 1 3}$ & $\begin{array}{c}\text { GOVERNMENT } \\
\text { SPENDING AS \% OF GDP }\end{array}$ & $\begin{array}{l}\text { 1990 } \\
\text { SPENDING \% AS OF GDP }\end{array}$ & \\
\hline U.S. & $7.5 \%$ & $33 \%$ & $25.5 \%$ \\
Spain & $11 \%$ & $42 \%$ & $31 \%$ \\
Japan & $8 \%$ & $32 \%$ & $24 \%$ \\
France & $17 \%$ & $50 \%$ & $33 \%$ \\
Netherlands & $9 \%$ & $54 \%$ & $45 \%$ \\
\hline
\end{tabular}

Source: Gerber, Hall \& Hines (2004)

Vickers and Yarrow (1998) state that the reasons for privatization through M\&As are: improving efficiency; reducing borrowing by public sector; reducing government involvement in decision making for enterprises; easing problems of public sector by pay determination; increasing share ownership; and gaining political ownership. Megginson (2000) argues that a government pursues privatization in order to increase efficiency; introduce competition; bring market 
discipline to public enterprise; encourage involvement by foreigners; increase share ownership; and raise revenue for the government.

The performance of an organization can be measured in terms of the relationship between inputs, outputs, and outcomes. Therefore, the ratio between outputs and inputs is a measure of efficiency, technical efficiency, x-efficiency, or productivity. Effectiveness measures the degree in which the outcomes match the original goals and objectives by the organization (Kloss, 2000). A study conducted by Majumdar (1996) looked at efficiency between government-owned, mixed and private sector enterprises in India which supported the superior efficiency of private and mixed sector firms over SOEs. Table 4 summarizes the findings.

Table 4. Type of ownership and average efficiency score

\begin{tabular}{ll}
\hline TYPE OF OWNERSHIP & AVERAGE EFFICIENCY SCORE \\
\hline SOE & 0.658 \\
Mixed & 0.92 \\
Private & 0.975 \\
\hline
\end{tabular}

Source: Majumdar (1996)

Dan et al. (2012) sought to assess the impact of New Public Management style reform in European countries and the effects of privatization and agencification. Agencification has been seen as a route for economies to reduce inputs and improve professional management such as processes in order to gain efficiency, improve output, input ratio, and to higher customer service, service quality, and improved outcomes. Analysis of 72 studies by Dan et al. (2012) indicates that in many cases, there has been an improvement in management and professionalism of agencies, and deterioration has also been observed. In Austria, there has been an improvement in saving and efficiency. However, studies show that in Belgium and the UK efficiency has been unchanged or at most experienced minor improvement.

There are some factors that impact privatization and its effectiveness. One of the key components of privatization is management change. However, this is contingent upon the method of privatization which defines who the new owners are and what kind of corporate governance will be implemented; the degree of prior restructuring experience; and deregulation and liberalization. The cumulative effect of these factors might lead to a change of management, which leads to changes in goals, strategies, and will impact performance of the firm (Cuervo \& Villalonga, 2000). Empirical studies demonstrate that there is a relationship between firms' ownership and their financial performance. SOEs have a lower financial performance than private firms in both developed and emerging economies (Megginson \& Netter, 2001). In their study, Chen, Firth, Xin and Xu (2008) found that a change in the largest shareholders at the firm listed on the Chinese stock market had a positive effect on profitability of the firm when change of control is passed from state to private entity and there is no effect when the transaction is to or within a state entity. This suggests that state ownership weakens the sensitivity of top leadership turnover to firm profitability (Shen \& Lin, 2009). Additionally, the study suggests that the partial privatization of SOEs or hospitals is not as beneficial as full privatization and results of a study conducted by Ramasamy, Ong, and Yeung (2005) suggest that ownership is the most important determinant of profitability. They showed that privately owned plantation companies in Malaysia have higher level of profitability than SOEs, which is consistent with other empirical studies.

A study conducted by Megginson and Netter (2001) summarizes the performance of a privatized firm (operating and financial) from three empirical studies analyzing profitability, efficiency, investment, output, and employment and it shows improvement in all categories. Megginson, Nash, and van Randenborgh (1994) conducted a study that compared the pre- and post-privatization performance of 61 firms in 32 industries in 18 different countries. The results showed a significant increase in profitability, output per employee, capital spending, and employment after privatization. In Nepal, the impacts of privatization of SOEs are found to be positive and it has accomplished the following results: increased production and diversification; improved technology; reduced financial losses; reduced financial burden of government; increased investment in private sector; and increased quality of goods and services (Raut, 2012). The International Finance Corporation (IFC) advised the Kenyan government on privatization of Kenya Airways and a study was conducted by Ochieng and Ahmed (2014) to determine the impact of privatization and financial performance of the national flag carrier. The results of the study showed that liquidity, debt ratio, financial efficiency, asset turnover, income efficiency, and capital expenditure were all improved post privatization. 
Chatterjee (2008) and Nadkarni (2010) assert that empirical evidence shows that the reason for the growth of the private health sector in India has been failure of the public health sector to meet the needs of patients. The number of admissions in public hospitals in Poland dropped after privatization. The patients' opinion was that the quality of services improved and private hospitals were better. Private hospitals were also more efficient and the length of stay in private hospitals was 5.8 days versus 6.9 days in public hospitals. The number of patients admitted per bed in private hospitals was 38.7 versus 38.2 in public hospitals, which is a clear indication that private hospitals were more productive (Siuda \& Romaniuk, 2006). Harris, Ozgen \& Ozgen (2000) showed that after a horizontal merger hospital efficiency increased and input utilization was reduced (scale efficiency). According to Villa and Kane (2013), privatization of public hospitals leads to increased operating margins, a reduced length of stay, and improved occupancy. Tiemann and Schreyögg (2012) investigated the impact of privatization on efficiency of hospitals in Germany. They demonstrated that conversion from public to for-profit private hospitals improved efficiency between 2.9 to $4.9 \%$.

\section{Research Philosophy and Methodology}

\subsection{Research Philosophy}

The research philosophy for this study was applied exploratory mixed method and is based on post-positivism, which is a philosophical approach that focuses on verifying hypothesis, i.e. rationalism, the capacity to reason, and empiricism based on sensory experience. The emphasis of post-positivist research is on inferential statistics and focuses on assigning probabilities that the findings as observed, are correct (Gray, 2014).

\subsection{Research Design}

\subsubsection{Exploratory Research}

A focus group is useful for exploring ideas and concepts when the research subject is new or vague and to obtain in-depth information and what participants think about an issue; it allows probing and it should not be the only method for data collection (Christensen, Johnson \& Turner, 2011). Focus group and in-depth interviews were held with participants from the target population, (Level 4, 5, and 6 hospitals) that included a Chairperson of the Board, Chief Executive Officer, Chief Operating Officer and Chief Financial Officer were conducted in order to understand the participants' viewpoints regarding the determinant of the effectiveness of hospital privatization through mergers and acquisitions and to solicit their views regarding the research topic, which led to the refinement of the developed self-administered questionnaire before piloting it.

\subsubsection{Mixed Method}

This research used mixed methods (qualitative and quantitative) to collect data. The qualitative or unstructured method was used to explore the nature of the problem. The quantitative or structured study is more appropriate to determine the extent of the problem. The mixed method is based on compatibility thesis and follows the philosophy of pragmatism and the idea is that quantitative and qualitative methods are complementary to each other and can be used effectively together in a single research study (Christensen, Johnson \& Turner, 2011). The qualitative approach helped to explore the determinant of the effectiveness of hospitals privatization through M\&A and comments were obtained from participants through focus group and in-depth interviews. A self-administered structured questionnaire, the quantitative approach, was used to explain the relationship between the dependent and independent variables. A mixed method approach yields a better result and allows for an opportunity to compensate for the weakness of each method, it capitalizes on strengths of each method and it offsets the inevitable method biases (Green, 2013).

\subsection{Population, Sampling, Design, Frame and Technique}

The population or sampling frame of the study was hospitals in Kenya with at least 50 beds, designated as Levels 4 , 5 and 6. In quantitative research randomization is used to ensure that a sample is selected in such a way that it represents the study population (in this case Levels 4, 5 and 6 hospitals) and avoids bias. Therefore, simple random sampling, clustering, stratification and random or probability sampling is used, which gives each element of the population an equal and independent chance of selection (Bryman \& Bell, 2011; Kumar, 2014).

In order to develop the sampling frame the Ministry of Health portal was accessed on March 11, 2016 and the list of all the healthcare facilities in Kenya was retrieved (total population of 10,068 institutions). The Kenya Medical Practitioners and Dentists Board portal was also accessed on March 14, 2016 and the list of healthcare facilities was retrieved and included 2,360 facilities. Both lists were merged to develop a comprehensive list of healthcare facilities (sampling frame) in Kenya. During this exercise, discrepancy between both lists such as number of beds and level was discovered. Both lists were further refined by eliminating the following columns: county; district; division; 
sub-location; constituency; nearest town; plot number; open 24 hours; open weekends; cost; and operational status. Seven columns were chosen: facility name; type; owner; province; location; Kenya Essential Package for Health $(\mathrm{KEPH})$ levels; and number of beds. A list was developed including these columns and all the Level 4, 5, and 6 hospitals. This list was further refined to include Level 4, 5 and 6 hospitals with at least 50 beds, which resulted in a sample (population) frame of 571 Level 4, 25 Level 5, and 9 Level 6 hospitals. This list was further refined to include only hospitals with at least 50 beds in Level 4 according to the definition by the Kenya Medical Practitioners and Dentists Board. Therefore, the sampling frame was reduced to 234 hospitals in Level 4 and resulted in a total population of 268 hospitals.

This research used multistage stratified random probability sampling. The first stage was to stratify hospital population by Levels 4, 5 and 6 (stratum). The second stage was to determine the procedure for selecting a stratified sample, which was a proportionate stratified sampling and the last stage was randomly selecting units from each hospital level. This method allowed representation from each hospital level (Bryman \& Bell, 2011; Kumar, 2014).

\subsection{Sample Size}

The sample size was determined as 158 hospitals after triangulation of different methods and proportionate stratified sampling was used to determine the sample size of each hospital level as shown in Table 3.1.

Table 5. Sample size by hospital level

\begin{tabular}{lllll}
\hline $\begin{array}{l}\text { Hospital } \\
\text { level }\end{array}$ & $\begin{array}{l}\text { Population by level } \\
\text { n }\end{array}$ & $\begin{array}{l}\text { Proportion } \\
\text { P \% }\end{array}$ & Total sample size & Sample size by level Pxn \\
\hline 4 & 234 & $87 \%^{(1)}$ & 158 & 137 \\
5 & 25 & $9 \%$ & 158 & 14 \\
6 & 9 & $4 \%^{(2)}$ & 158 & 7 \\
Total & $\mathbf{2 6 8}$ & $\mathbf{1 0 0 \%}$ & $\mathbf{1 5 8}$ & $\mathbf{1 5 8}$ \\
\hline
\end{tabular}

Source: Author (2016)

1) $\frac{234}{268} \times 100=87 \%$

2) Level 6 numbers were rounded from $3.35 \%$ to $4 \%$ and sample from size 6.32 to 7 .

\subsection{Data Collection Methods and Analysis}

This study was a cross-sectional research and data were collected at a single point in time. Sources of the collected data were primary data and secondary data (Simam \& Rotich, 2011). Primary data were collected through in-depth interviews, which can be structured or unstructured and self-administered, mail and online questionnaires.

In September 2016, 28 questions were drafted and 14 questions were selected for information gathering concerning the determinant of the effectiveness of hospitals privatization through mergers and acquisitions in order to utilize the results to refine the drafted research instrument. The first interview was conducted in late September 2016 in order to pilot the questions and the participant was a CEO of a Kenyan private hospital that recently sold its stake to a foreign equity firm. There was a consensus that the questions were appropriate and question number 15 was added at the end of the interview. In the second phase 16 individuals were targeted for focus group or in-depth interviews: 4 Chairpersons of the Board (COB); 4 Chief Executive Officers (CEO); 4 Chief Operating Officers (COO); and 4 Chief Financial Officers (CF). Eleven individuals participated including 7 individuals for in-depth interviews and 4 in a heterogeneous focus group. It was difficult to get individuals who participated in focus groups to willingly share their opinions; therefore, it was decided to conduct in-depth interviews and discontinue focus groups. The participants were from Level 4, 5 and 6 hospitals.

Responses to exploratory questions 1 to 15 were combined. Microsoft Excel, IBM text analysis, SPSS software and natural language processing techniques were used to perform sentiment / keyword extraction analysis. The results were used to finalize the research instrument (self-administered structured questionnaire). Literature search based on proposed theoretical framework for privatization through M\&A and conceptual framework generated additional 
questions based on theories, motivations and empirical studies. These questions were added to the research instrument before piloting the questionnaire.

\subsection{Reliability and Pilot Testing}

Castillo (2009) suggests the following rules of thumb for internal reliability: CAC $>0.9-$ excellent; CAC > $0.8-$ good; CAC > 0.7 - acceptable; CAC > 0.6 - questionable; CAC > 0.5 - poor; and CAC $<0.5$ - unacceptable.

Twenty questionnaires were administered during one-on-one interviews and information was collected to establish the reliability of the survey questionnaire. IBM SPSS statistical software was used to measure Cronbach's alpha using SPSS's reliability analysis procedure. A Cronbach's alpha of 0.83 was achieved.

\subsection{Administration of the Instrument}

The research instrument was a self-administered questionnaire with a Likert scale of 1 (lowest) to 5 (highest) and included sections on demography, consisting of 10 questions and top leadership, consisting of 19 questions with $\alpha=$ 0.83, which was sent to the senior hospital leadership who were COB, CEO, COO, CFO and other senior managers of randomly selected hospitals, to be completed.

\subsection{Data Analysis, Descriptive and Inferential Statistics}

Sullivan and Artino (2013), Norman (2010), Carifio and Perla (2008) argue that it is permissible to use parametric tests when using Likert scales. Consequently, parametric tests were used to analyze the collected data. Hyndman (2008) states that data processing includes translating the answers to the questionnaire into a format that can be manipulated to produce statistical results. The response rate to self-administered questionnaires was calculated using the following formula (Bryman \& Bell, 2011).

$$
\frac{\text { number of usable questionnaires }}{\text { total sample }- \text { unsuitable or uncontactable numbers of the sample }} \times 100
$$

The Statistical Package for Social Sciences software (SPSS) was used for descriptive and inferential statistical analysis to draw a conclusion from the sample population. Descriptive statistics starts with data sets and deals with arranging and describing the collected data and these measures also give the idea of the overall distribution of observations in the data set (Weiss, 2012; Kothari \& Garg, 2014). Descriptive statistics helps researchers to communicate the important characteristics of the collected data. Inferential statistics uses random sampling and data to make generalizations about a population. Inferential statistics deals with methods that can use collected data from a sample (small group) to draw conclusions about a population (larger group) (Levine, Stephan, Krehbiel \& Berenson, 2013).

\section{Results and Findings}

\subsection{Response Rate and Demographics}

The intent of this research was to collect data from a sample of 158 hospital top leaders (COB, CEO, COO, CFO and CNO) of Level 4, 5 and 6 hospitals in Kenya. Out of the 158 targeted hospital leaders, only 50 respondents provided information and a response rate of thirty two percent $(32 \%)$ was achieved.

Demographic analysis indicated that fifty two percent $(52 \%)$ of the participants were from Level 4 hospitals. Eighty six percent $(86 \%)$ of the respondents were senior management of the hospitals and sixty three percent $(63 \%)$ of them had a background in medicine, followed by twenty three percent $(23 \%)$ in business administration. Ninety six percent $(96 \%)$ of participants had Bachelors and Masters degrees and seventy six percent $(76 \%)$ of them had less than 5 years of experience in their position. Sixty four percent $(64 \%)$ of the hospitals were government and county sponsored NFP hospitals and twenty one percent (21\%) were private NFP and religious NFP hospitals. Therefore, eighty five percent $(85 \%)$ of the hospitals that participated in this study were NFP and fifteen percent (15\%) of the hospitals were for-profit (FP). Seventy percent (70\%) of the hospitals had experienced revenue growth ranging from $1 \%$ to $19 \%$ and eighty eight percent $(88 \%)$ of participating hospitals had not experienced any decline in revenue growth (see Appendix 1).

\subsection{Effect of Top Leadership on the Effectiveness of Privatization of Hospitals Through M\&A}

The intent of the study was to determine the influence of top leadership (COB, CEO, COO, CFO and CNO) on the effectiveness of privatization of hospitals through M\&A. This was examined by evaluating the awareness of top managers on how top leadership could influence privatization of hospitals. The findings are portrayed using both descriptive and inferential statistics, and evaluation of statistical assumptions was also performed. The responses 
were rated on a Likert scale (1 through 5), frequency percentage, mean (M) and standard deviation (SD) of responses were calculated as shown in Appendix 2 and organized in descending order.

\subsection{Descriptive Findings for Top Leadership}

Results indicate that the mean scores ranged from 2.65 to 4.61. The highest mean score was related to participants expressing the need for awareness by top leadership on the following: the impact of privatization on staff; followed by the requirement that top leadership understands the risk of privatization through $\mathrm{M} \& \mathrm{~A}(\mathrm{M}=4.57, \mathrm{SD}=0.677$ and the majority expressing agreement at $81.7 \%)$; understanding the impact of privatization on the public $(\mathrm{M}=4.41, \mathrm{SD}$ $=0.814$ and majority expressing agreement at 93.9\%); management's understanding of multidimensional view of agreement, specifically actual agreement $(\mathrm{M}=4.27, \mathrm{SD}=0.861$ and majority of $83.6 \%$ expressing agreement); and understanding that a multidimensional view of agreement can create synergy $(\mathrm{M}=4.27, \mathrm{SD}=0.792$ and majority of $73.3 \%$ agreeing).

"Top management must understand a multidimensional view of the privatization agreement" (perceived agreement) had mean score of $(\mathrm{M}=3.88, \mathrm{SD}=0.922$ and majority of $66.3 \%$ agreed $)$ followed by role of government after privatization $(\mathrm{M}=3.85, \mathrm{SD}=1.042$ and majority of $78.7 \%$ agreed); "understanding a multidimensional view of agreement will reduce complexity" ( $\mathrm{M}=3.83, \mathrm{SD}=0.907$ and majority of $66.7 \%$ agreeing); and type of buyer as the most important aspect of privatization of public hospitals $(\mathrm{M}=3.81, \mathrm{SD}=0.924$ and majority of $70.2 \%$ agreeing).

Participants strongly disagreed with the statement that the provision of healthcare services in Kenya must shift from public sector focus to private sector focus $(\mathrm{M}=2.65, \mathrm{SD}=1.480$ and majority of $53 \%$ disagreeing). Adding the proportion of uncertain respondents increased the percentage to sixty seven percent (67\%) who disagreed with privatization of public hospitals. Thirty three percent $(33 \%)$, a minority, were in favor of privatization of public healthcare sector (see Appendix 2).

\subsection{Normality Test of Data for Top Leadership}

Prior to analyzing data using inferential statistical techniques, normality of the data set was tested by conducting the following tests: detrended normal Q-Q plot; normal Q-Q plot and normal histogram plot; kurtosis; skewness; Shapiro-Wilk; Kolmogorov-Smirnov; and homoscedasticity and these tests indicated that the data were normally distributed as shown in Tables 6,7 and 8.

Table 6. Skewness - Kurtosis values for top leadership

\begin{tabular}{lllllll}
\hline $\mathrm{N}$ & Mean & Skewness & \multicolumn{3}{c}{ Kurtosis } \\
\hline Valid & Missing & & Statistic & Std. Error & Statistic & Std. Error \\
48 & 2 & 3.8882 & -2.497 & .343 & 7.597 & .674 \\
\hline
\end{tabular}

Source: Author (2017)

Table 7. Normality tests for top leadership

\begin{tabular}{|c|c|c|c|c|c|c|c|}
\hline & \multirow[t]{2}{*}{ Top Leadership } & \multicolumn{3}{|c|}{ Kolmogorov-Smirnov ${ }^{\mathrm{a}}$} & \multicolumn{3}{|c|}{ Shapiro-Wilk } \\
\hline & & Statistic & Df & Sig. & Statistic & df & Sig. \\
\hline \multirow{9}{*}{$\begin{array}{l}\text { Effectiveness } \\
\text { Privatization }\end{array}$} & 3.33 & .171 & 5 & $.200^{*}$ & .983 & 5 & .952 \\
\hline & 3.50 & .260 & 2 & . & & & \\
\hline & 3.67 & .287 & 5 & $.200^{*}$ & .914 & 5 & .490 \\
\hline & 3.83 & .178 & 5 & $.200^{*}$ & .981 & 5 & .940 \\
\hline & $\mathrm{of}_{4.00}$ & .357 & 7 & .007 & .777 & 7 & .024 \\
\hline & 4.17 & .333 & 7 & .018 & .826 & 7 & .073 \\
\hline & 4.33 & .212 & 6 & $.200^{*}$ & .933 & 6 & .607 \\
\hline & 4.50 & .226 & 4 & . & .976 & 4 & .880 \\
\hline & 4.67 & .260 & 2 & . & & & \\
\hline
\end{tabular}

Source: Author (2017) 
Table 7 indicates that data were normally distributed for top leadership as significant p-values obtained were all greater than $\mathrm{p}>0.05$.

Table 8. Homoscedasticity test for top leadership

\begin{tabular}{llll}
\hline Levene Statistic & df1 & df2 & Sig. \\
\hline 2.064 & 8 & 34 & .068 \\
\hline
\end{tabular}

Source: Author (2017)

Levene's test was conducted at $5 \%$ level of significance. The results obtained were for $\mathrm{F}(8,34)=0.2064$ and $\mathrm{p}$-value $=0.068$. The $\mathrm{p}$-value $(0.068>0.05)$ indicates no significant difference between the two variances as shown in Table 8.

\subsection{Results of Hypothesis Tests}

4.5.1 Correlation Analysis Between Top Leadership and Effectiveness of Privatization

The Pearson correlation test was performed to determine the relationship between top leadership (IV) and effectiveness of privatization (DV). The correlation coefficient (r) depicts the relationship between two variables. They were strongly and positively correlated at $5 \%$ significance level $(\mathrm{r}=.821)$ and $(\mathrm{p}<0.005)$ as shown in Table 4.4.

Table 9. Correlation between top leadership and effectiveness of privatization

\begin{tabular}{llll}
\hline & & $\begin{array}{l}\text { Effectiveness } \\
\text { privatization }\end{array}$ & ofTop leadership \\
\hline \multirow{2}{*}{ Effectiveness of Privatization } & Pearson Correlation & 1 & $.821^{* *}$ \\
& Sig. (2-tailed) & & .000 \\
& $\mathrm{~N}$ & 48 & 48 \\
Top leadership & Pearson Correlation & $.821^{* *}$ & 1 \\
& Sig. (2-tailed) & .000 & 48 \\
$* *$ Correlation is significant at the 0.01 level (2-tailed). & 48 & \\
\hline
\end{tabular}

Source: Author (2017)

\subsubsection{Regression Analysis for Top Leadership and Effectiveness of Privatization}

The study found that top leadership explained a significant proportion of variance in the effectiveness of privatization; the coefficient of determination $\mathrm{R}^{2}$ is equal to $0.674\left(\mathrm{R}^{2}=821 \mathrm{x} .821=0.674\right)$. This implies that $67.4 \%$ of the proportion in effectiveness of privatization can be explained by top leadership in the hospitals. Other factors not covered contribute to $32.6 \%$ that cannot be explained by the model summary.

\subsubsection{Simple Regression Model for Top Leadership and Effectiveness of Privatization}

Based on the simple regression model $\mathrm{Y}_{i}=\beta 0+\beta_{1} \mathrm{X}_{i}+\varepsilon_{i}$ and the data regarding the impact of top leadership on the effectiveness of privatization of hospitals the regression equation is as below. Also see Table 4.5.

$$
\hat{\mathrm{Y}}=0.314+0.925 \mathrm{X}_{1}+0.372
$$

$\mathrm{Y}=$ effectiveness of privatization

$\mathrm{X}_{1}=$ top leadership

The model implies that for every unit of increase in top leadership, effectiveness of privatization increases by $92.5 \%$. 


\subsubsection{Inferential Statistics T-test for Hypothesis Testing}

T-tests for population correlation coefficient $\rho$ (rho) and regression slope $\beta_{1}$ (Beta) were performed to depict the relationship between variables and to establish the influence of top leadership on effectiveness of privatization by testing the following hypothesis:

Hypothesis - There is no relationship between top leadership $(\mathrm{X})$ and the effectiveness of hospitals privatization through M\&A (Y)

$\mathrm{H}_{0}: \rho=0$ (there is no relationship between $\mathrm{X}$ and $\mathrm{Y}$ )

$\mathrm{H}_{\mathrm{A}}: \rho \# 0$ (there is a relationship between $\mathrm{X}$ and $\mathrm{Y}$ )

$\mathrm{H}_{0}: \beta_{1}=0$ ( $\mathrm{X}$ or predictor value is not useful for predicting $\mathrm{Y}$ or the slope is zero)

$\mathrm{H}_{\mathrm{A}}:{ }_{1} \# 0$ ( $\mathrm{X}$ or predictor value is useful for predicting $\mathrm{Y}$ or the slope is not zero)

The study indicated that top leadership significantly predicted effectiveness of privatization, since its slope $\beta_{1}=$ 0.925 has a $t=9.757$ and $\mathrm{p}<0.005$. These findings and observed significance and the $\mathrm{p}$-value $(\mathrm{p}<0.05)$ implied rejection of the null hypothesis $\left(\mathrm{H}_{0}\right)$ and acceptance of $\left(\mathrm{H}_{\mathrm{A}}\right)$. These results show that top leadership and effectiveness of privatization are positively and strongly correlated $(\mathrm{r}=.821)$, i.e. that top leadership significantly influences the effectiveness of privatization in hospitals. This indicates a significance level of 5\% and implies that for every unit of increase in the level of influence by top leadership in M\&A, the effectiveness of privatization increases by $92.5 \%$.

Table 10. Coefficients for top leadership

\begin{tabular}{|c|c|c|c|c|c|c|}
\hline \multirow[t]{2}{*}{ Model } & & \multicolumn{2}{|c|}{ Unstandardized Coefficients } & \multirow{2}{*}{$\begin{array}{l}\text { Standardized } \\
\text { Coefficients } \\
\text { Beta }\end{array}$} & \multirow[t]{2}{*}{$\mathrm{t}$} & \multirow[t]{2}{*}{ Sig. } \\
\hline & & B & Std. Error & & & \\
\hline \multirow{2}{*}{1} & (Constant) & .314 & .372 & & .845 & .403 \\
\hline & Top leadership & .925 & .095 & .821 & 9.757 & .000 \\
\hline
\end{tabular}

Source: Author (2017)

\subsubsection{ANOVA Test for Significance of the Regression Model for Top Leadership and Effectivenes of Privatization}

The ANOVA test was performed to determine if the regression model between top leadership and effectiveness of privatization was significant. The null hypothesis was that top leadership does not influence the effectiveness of privatization. The results as provided in Table 4.6 indicate that $F(1,46)=95.204$ and $p$-value $<0.005$, which is significant at the $5 \%$ level and a confidence interval of $95 \%$ indicated that top leadership influences effectiveness of privatization.

Table 11. ANOVA Test for regression model of top leadership and effectiveness of privatization

\begin{tabular}{lllllll}
\hline Model & & Sum of Squares & df & Mean Square & F & Sig. \\
\hline \multirow{2}{*}{1} & Regression & 18.698 & 1 & 18.698 & 95.204 & $.000^{\mathrm{b}}$ \\
& Residual & 9.034 & 46 & .196 & & \\
& Total & 27.732 & 47 & & &
\end{tabular}

a. Dependent variable: effectiveness of privatization

b. Predictors: (Constant): top leadership

Source: Author (2017)

4.5.6 Chi-square Test for Gender and Top Leadership

The researcher conducted tests of association using Chi-square. The null hypothesis was that there was no significant association between gender and the aspects evaluated on top leadership, whereas the alternative hypothesis was that significant association existed. The majority of the aspects did not reveal significant associations with gender at 5\% 
level of significance, with the exception of 'understanding the multidimensional view of agreement during privatization will help with smooth integration'. Leadership of public hospitals are not well equipped to compete in the competitive market and resources of a firm including top leadership and entrepreneurship influence its value during privatization and M\&A. The caveat, however, should be observed in the interpretation, given that the tests violated the assumption regarding expected cell counts. Appendix 3 summarizes the results.

\section{Summary, Discussion, Conclusion and Recommendation}

\subsection{Effect of Top Leadership on the Effectiveness of Hospitals Privatization Through M\&A}

During the exploratory phase, focus group and in-depth interviews, participants expressed that the leadership role is important since leaders know the dynamic of their organizations and can impact the effectiveness of M\&A. Analysis of data indicates that ninety eight percent (98\%) of respondents expressed the need for awareness by top leadership ( $\mathrm{COB}, \mathrm{CEO}, \mathrm{COO}, \mathrm{COS}$ and $\mathrm{CNO}$ ) on the impact of privatization on staff and ninety three percent (93\%) on the public. Therefore, it is important for management to be familiar with different management theories concerning M\&A's impact on stakeholders. Beer and Nohria (2000) proposed that there are two types of leaders, the task-oriented leader (theory E) and the person-oriented leader, who knows how to manage change. According to Battilana et al. (2010) person-oriented (theory O) leaders focus on communication and change management. Balance between task orientation and people orientation can contribute to the transformational leadership style. Nemanich and Keller (2007) argue transformational leadership has a positive relationship with the performance of an acquisition job satisfaction. A study by Bratianu and Anagnoste (2011) analyzed the role of transformational leadership in M\&A in emergent economies and it was found that the following factors were important during M\&A: the vision of the leader; his relationship with the group; trust; ethical and moral decision making; optimism; motivation; and emotional intelligence. Sanda \& Adjei-Benin (2011) conducted a study in Ghana based on justice and anxiety theory to determine how M\&A affects employee satisfaction and performance. They found that lack of communication, trust, anxiety and stress impacted employees' productivity. Trust in top leadership of the institution during M\&A was important to eighty six percent (86\%) of respondents. A study conducted by Hellgren et al. (2005) found that leadership, trust, and justice were related positively in FP hospitals and NFP hospitals compared to public hospitals.

Understanding the risk of M\&A by top leadership was another concern expressed by eighty two percent (82\%) of respondents. According to Shleifer (1998), privatization of SOEs such as public hospitals is a dynamic and complex process and it is difficult to hold leadership accountable. In order to mitigate this risk it is paramount for top leadership to understand the market based view approach (MBV) and resource based view approach (RBV) to M\&A and privatization to be able to properly understand and determine fair market value (Porter, 1979; Wernerfelt, 1984).

Understanding the multidimensional view of agreement during M\&A and privatization was also deemed important by eighty four percent $(84 \%)$ of respondents. They expressed that its understanding can create synergy, smooth integration, and reduce complexity and stress. This confirms findings of the study conducted by Shanley and Correa (1992) regarding understanding of the three dimensions of agreement, i.e. perceived agreement, actual agreement, and accuracy of agreement, which can impact the process of merger, acquisition and implementation.

Prior experience in M\&A was considered important by seventy five percent (75\%) of respondents. Makhija (2003) argues that prior experience by managers in M\&A in competitive environments has a beneficial effect on shareholder value.

Participants were asked questions on replacement of leadership, improvement of governance, incentives, competitiveness, and improvement of operation of public hospitals. The majority of respondents (53\% to 89\%) agreed that privatization will improve operation of public hospitals. For example, there was an agreement among seventy percent $(70 \%)$ of respondents that privatization of public hospitals improves governance, leadership and performance. These findings confirm studies conducted by Shah and Mohanty (2010), Ramamurti (2000), Jarrell and Poulsen (1998) and concluded that privatization of hospitals can remove inefficient management due to improvement of governance.

There was an agreement among eighty nine percent (89\%) of respondents that privatization will improve revenue, product mix, and growth of services. Shen and Lin's (2009) study determined that state ownership weakens the relationship between firm performance and top leadership turnover. Cuervo and Villalonga, (2000), Parrino, College and Harris (1999), Castanias and Helfat (1991), Shen and Lin (2009) assert that the easiest way to break resistance to change and improve performance in SOEs is to change top leadership, which will have a positive impact on financial performance. 
Analysis of the collected data from participating hospitals found that there was a strong and positive relationship $(\mathrm{r}=$ 0.821 ) between top leadership (X) and effectiveness of privatization of hospitals (Y) and the regression model was reliable. For every unit of increase in top leadership, the effectiveness of privatization would increase by $92.5 \%$. The findings and t-tests $(\beta=0.925, \mathrm{t}=9.757, \mathrm{p}<0.005)$ also confirmed that there was a positive relationship between the influence of top leadership (X) and the effectiveness of privatization of hospitals (Y).

A surprise finding was that $53 \%$ to $67.3 \%$ of participants disagreed with the statement that the provision of healthcare services in Kenya must shift from public sector focus to private sector focus, which contradicts the findings of the studies by Patel et al., (2010) and Pinto and Udwadia (2010). These studies showed that the majority of Indian households (62\%) preferred private healthcare facilities.

Analysis of the questionnaires indicated that sixty eight percent $(68 \%)$ of the respondents in senior management position had a medical degree and twenty three percent (23\%) a business degree. Are these leaders equipped with expertise to participate in privatization, M\&A implementation? One might infer that the top leadership of Kenyan hospitals have not engaged with their constituents regarding the performance of their hospitals and might not possess the requisite knowledge and experience to engage in privatization activities. The majority of the findings are similar to responses to the questions asked during focus group and in-depth interviews.

\subsection{Conclusions}

\subsubsection{Effect of Top Leadership on the Effectiveness of Hospitals Privatization Through M\&A}

The results and findings determined that there was a strong and positive correlation between the influence of top leadership and the effectiveness of privatization. The implication is that understanding of management theories related to M\&A, such as transformational leadership, factors influencing successful M\&A, understanding of multidimensionality of agreements during M\&A (perceived, actual and accuracy of agreement), or change of governance and management are of paramount importance for top leadership. Despite agreement among respondents that privatization improves performance, sixty seven percent (67\%) were against the shift of healthcare from the public to private sector, which might be attributed to lack of knowledge among hospital leaders as determined by the results of the Chi-square test for gender and top leadership and since privatization, M\&A in healthcare is a new phenomenon in Kenya. In summary, there a conceptual knowledge gap among hospitals leadership regarding privatization, M\&A of hospitals.

\subsection{Suggestions for Further Research and Recommendations}

A study conducted by Ellis et al. (2015) reviewed 30 papers related to M\&A in Africa. The majority of these papers were related to banking and there was none addressing $M \& A$ in the healthcare industry in Africa. Therefore, further research in this area is justified and it is recommended to study the reasons why there is an objection by Kenyan hospital leaders to privatize public and not-for-profit hospitals despite participants' agreement that privatization improves efficiency and quality.

This study should be repeated in other East African countries to understand if this determinant of the effectiveness of privatization is valid. South Africa will be a good place to conduct further research since its market is more mature and there are at least three for-profit health systems. The aforementioned suggested studies will enable researchers and practitioners to identify potential differences in these countries and conduct comparative analyses.

These further studies can contribute to the understanding of the privatization and M\&A process of hospitals in Africa and it is important since this research revealed that there is insufficient knowledge concerning privatization, M\&A of hospitals and relevant literature concerning this topic is scarce in Africa.

Lastly, universities should offer a course regarding the process of privatization of public institutions/hospitals to benefit leadership of these organizations, policy makers, and government officials. Governments must develop a clear definition of property rights, relevant laws, regulations and antitrust statutes to facilitate the privatization process and use of the proceeds for setting up of conversion foundations.

\section{References}

Action Platform Health and Solidarity. (2014). Retrieved from http://eurohealthneteu/organisation/equity-action-high

African Union. (2003). Maputo Declaration on Malaria, HIV/AIDS, Tuberculosis and other Infectious Diseases. African Union, Addis Ababa.

Alchian, A. A., \& Demsetz, H. (1978). The Property Right Paradigm. The Journal of Economic History, 33(1), 16-27. 
Allen, D. W. (1999). Transaction Costs. Enclyclopedia of Law and Economics.

Angwin, D. (2007). Motive Archetypes in Mergers and Acquisitions (M\&A): The Implications of Configuration Approach to Performance. Advances in Mergers and Acquisitions, 6, 77-105.

Arnold, G. (2013). Corporate Financial Management (5th ed.). Essex, England: Pearson Education Limited.

Avenue Group. (2016). Avenue Group Profile.

Barney, J. (1991). Firm Resources and Sustained Competitive Advantage. Journal of Management, 17(1), 99-120.

Barney, J. B., \& Hesterly, W. (1996). Organizational Economics: Understanding the Relationship between Organizations and Economic Analysis. In Clegg, S. R., \& Hardy, C. (Eds.), Studying Organization - Theory and Method (1999). Thousand Oaks, CA: Sage.

Battaglio, P., \& Legge, J. (2008). Citizen Support for Hospital Privatization: A Hierarchical Cross-national Analysis. Public Organizations Review.

Battilana, J., Gilmartin M., Sengal, M., Claire-Pache, \& Alexander, A. J. (2010). Leadership Competencies for Implementing Planned Organizational Change. The Leadership Quarterly, 21, 422-438.

Beer, M., \& Nohria, N. (2000). Breaking the Code of Change. Boston, MA: Harvard Business School Press.

Berk, J., DeMarzo, P., \& Harford, J. (2013). Fundamentals of Corporate Finance (2nd ed.). Essex, England: Pearson Education Limited.

Bratianu, C., \& Anagnoste, S. (2011). The Role of Transformational Leadership in Mergers and Acquisitions in Emergent Economies. Management \& Marketing Challenges for the Knowledge Society, 6(2), 319-326.

Bruner, R. F. (2004). Applied Mergers and Acquisitions. Hoboken, NJ: John Wiley and Sons.

Bruton, G. D., Ahlstrom, D., \& Li, H. L. (2010). Institutional Theory and Entrepreneurship: Where are we Now and Where do we Need to Move in the Future? Baylor University.

Bryman, A., \& Bell, E. (2011). Business Research Methods (3rd ed.). Oxford, England: Oxford University Press.

Business Daily. (2016). Malaysia Clinic Banks on Telemedicine to Tap Patients. Business Daily.

Butler, F. C., Perryman, A. A., \& Ranft, A. L. (2012). Examining the Effects of Acquired Top Management Team Turnover on Firm Performance Post-acquisition: A Meta-analysis. Journal of Management Issues, 24(1), 47-60.

Camaya Partners. (2014). The Seventh Merger and Acquisition Wave. Retrieved from www.camaya.com.br/site/es/insights/52/2014/.../the-seventh-m\&a-wave

Canning, D., Raja, S., \& Yazbeck, A. S. (2015). Africa's Demographic Transition: Dividend or Disaster? World Bank and Agence Francaise de Developpment.

Carbonara, G., \& Caiazza, R. (2009). Mergers and Acquisitions: Cause and Effects. The Journal of American Academy of Business, 14(2), 188-194.

Carifio, J., \& Perla, R. (2008). Resolving the 50-year Debate Around Using and Misusing Likert Scales. Medical Education, 42, 1150-1152.

Carrin, G., \& James, C. (2005). Social Health Insurance: Key Factors Affecting the Transition Towards Universal Coverage. International Society Security Review, 58(1), 45-64.

Carroll, G. R., Spiller, P. T., \& Teece, D. J. (1999). Transition Cost Economics: Its Influence on Organizational Theory, Strategic Management and Political Economy. In Carroll, G. R., \& Teece, D. J. (Eds.), Firms, Markets and Hierarchies (pp. 60-88). New York, NY: Oxford University Press.

Cartwright, S., \& Schoenberg, R. (2006). 30 Years of Mergers and Acquisitions Research: Recent Advances and Future Opportunities. British Journal of Management, 17(S1), S1-S5.

Castanias, R. P., \& Helfat, C. E. (1991). Management Resources and Rents. Journal of Management, 17(1), 155-171.

Castillo, J. J. (2009). Convenience Sampling. Retrieved from $\mathrm{http}: / / \mathrm{www}$.experiment-resources.com/conveniencesampling.html

Chand, G. (Ed.). (2009). Mergers and Acquisitions: Issues and Perspectives from the Asia-Pacific Region. Tokyo, Japan: APO. 
Chartered Financial Analyst Institute (CFA). (2013). Chapter 10: Mergers and Acquisitions. CFA Instittute. Retrieved from https://www.cfainstitute.org/..../corporate-finance-chapter10....

Chatterjee, P. (2008). Factors that Frustrate Growth of Private Health Sector in India. Retrieved from medind.nic.id/haa/t08/i1/haat08i1P5.pdf

Chatterjee, S. (1986). Types of Synergy and Economic Values: The Impact of Acquisitions on Merging and Rival Firms. Strategic Management Journal, 7, 119-139.

Chen, G., Firth, M., Xin , Y., \& Xu, L. (2008). Control Transfers, Privatization and Corporate Performance: Efficiency Gains in China's Listed Companies. Journal of Financial and Quantitative Analysis, 43, 161-190.

Christensen, L. B., Johnson, R. B., \& Turner, L. A. (2011). Research Methods, Design, and Analysis (11th ed.). Boston, MA: Allyn and Bacon.

Chuma, J., \& Okungu, V. (2011). Viewing the Kenyan Health System through an Equity Lens: Implication for Universal Coverage. International Journal for Equity in Health, 10(22). Retrieved from http://www.equityhealthj.com/content/10/1/22

Coase, R. H. (1937). The Nature of the Firm. Economica, 4, 386-405.

Collins. (2013). Abraaj Teams up for African Hospital Investment. Retrieved from www.themiddlemarket.com>news>abr

Cuervo, A., \& Villalonga. (2000). Explaining the Variance in the Peformance Effects of Privatization. Academy of Management Review, 25(3), 581-590.

Cyert, R. M., \& March, J. G. (1963). A Behavioral Theory of the Firm. Englewood, NJ: Prentice-Hall.

Dacin, M. T., Goodstein, J., \& Scott, W. R. (2002). Institutional Theory and Institutional Change: Introduction to the Special Research Forum. Academy of Management Journal, 45(1), 45-47.

Dan, S., Jilke, S., Pollitt, C., van Delft, R., van de Walle, S., \& van Thiel, S. (2012). Effects of Privatization and Agencification on Citizens and Citizenship: An International Comparison. European Commission. COCOPS.

Della Porta, D., \& Keating, M. (Eds.). (2008). Approaches and Methodologies in the Social Sciences. Cambridge, UK: Cambridge University Press.

Demsetz, H. (1998). Ownership Control and the Firm. New York, NY: Oxford University Press.

DeNoble, D. (2013). China Healthcare Reforms and Privatization. Health Intel Asia. Retrieved from https://healthintelasia.com/china-healthcare-reforms-privatization

DePamphilis, M. D. (2015). Mergers, Acquisitions and other Restructuring Activities (8th ed.). San Diego, CA: Elsevier Inc.

DiMaggio, P. J., \& Powell, W. W. (1983). The Iron Cage Revisited: Institutional Isomorphism and Collective Rationality in Organizational Fields. American Sociological Review, 48(2), 147-160.

DiMaggio, P. J., \& Powell, W. W. (1991). The New Institutionalism in Organizational Analysis. Chicago, IL: University of Chicago Press.

Dixon Hughes Goodman. (2013). What Hospital Executives Should be Considering in Hospital Mergers and Acquisitions. Retrieved from https://www.dhgllp.com/resources/publications/article/439/what-hospital-executives-should-be-considering-in-h ospital-mergers-and-acquist

Doherty, J. (2011). Expansion of the Private Health Sector in East and Southern Africa. EQUINET Discussion Paper 87. Harare: EQUINET Africa. Retrieved www.equinetafrica.org >documentssearch.forprofithospitalsinafrica

Ellis, M. K., Lamont, T. B., Reus, H. T., \& Faifman, L. (2015). Mergers and Acquisitions in Africa: A Review and an Emerging Research Agenda. Africa Journal of Management, 1(2), 137-171.

Evans, H. M. (2000). Course 7: Mergers and Acquisitions (Part 1). Excellence in Financial Management. Retrieved from www.exinfm.com/training/pdffiles/course07-1.pdf

Fan, V. F., \& Savedoff, W. D. (2014). The Health Financing Transition: A Conceptual Framework and Empirical Evidence. Social Sciences \& Medicine, 105, 112-121. 
Finkler, S., Ward, M. D., \& Baker, J. (2007). Essentials of Cost Accounting for Healthcare Organizations (5th ed.). Sudbury, MA: Jones and Barlet Publishers.

Gaddis, P. O. (1987). Taken Over, Turned Out. Harvard Business Review, 65, 8-22.

Gerber, R. E., Hall, K. C., \& Hines, R. J. (2004). Privatization Issues in Local And State Service Provision. Policy

Gort, M. (1969). An Economic Disturbance Theory of Mergers. Quarterly Journal of Economics, 83, 624-642.

Gray, E. D. (2014). Doing Research in the Real World. Retrieved from www.dphu.org/uploads/attachments/books-5343-0.pdf

Green, E. (2013). Qualitative Methods in Management Research. (2nd ed.). Thousand Oaks, CA: Sage.

Grossman, J. S., \& Hart, D. O. (1986). The Costs and Benefits of Ownership: A Theory of Vertical and Lateral Integration. Journal of Political Economy, 94(4), 691-719.

Hail. (2016). Saudi Arabia to Privatize 295 Hospitals. Retrieved from english.alarabiya.net2016/05/15>sau

Hamilton, W. F. (1990). The Dynamics of Technology and Strategy. European Journal of Operational Research, 47, 141-152.

Harris, J., Ozgen, H., \& Ozgen, Y. (2000). Do Mergers Enhance the Performance of Hospital Efficiency? Journal of The Operational Research Society, 51(7), 801-811.

Hart, O., \& Moore, J. (1990). Property Rights and the Nature of the Firm. Journal of Political Economy, 98(6), 1119-1158.

Hellgren, J., Sverke, M., Falkenberg, H., \& Baraldi, S. (2005). Physicians' Work Climate at Three Hospitals under Different Types of Ownership. In Korunka, C., \& Hoffman, P. (Eds.), Change and Quality in Human Service Work (pp. 47-65). Munich, Germany: Rainer Hampp.

Himmelstein, D., \& Woodhandler, S. (2008). Privatization in Publicly Funded Healthcare System: The US Experience. International Journal of Health Services, 38(3), 407-419. Retrieved from http://jon.sagepub.com/content/38/3/407.long

Holthausen, W. R., \& Zmijewski, E. M. (2014). Corporate Valuation: Theory, Evidence and Practice. Cambridge, MA: Cambridge Business Publishers, LLC.

Hyndman, R. (2008). Quantitative Business Research Methods. Monash University (Clayton Campus), Department of Econometrics and Business Statistics.

Irving Levin Associates. (2012). Healthcare Services Acquisition Report, Eighteenth Edition. Retrieved from IrvingLevinAssociates $>$ archives $>$ health

Jarrel, G. A., \& Poulsen, A. B. (1988). Dual-class Recapitalizations as Anti-takeover Mechanisms: The Recent Evidence. Journal of Financial Economics, 20, 129-152.

Jarrell, G. A., Brickley, J. A., \& Netter, J. M. (1988). The Market for Corporate Control: The Empirical Evidence Since 1980. Journal of Economic Perspectives, 2(1), 49-68.

Junni, P., \& Sarala, R. M. (2014). The Role of Leadership in Mergers and Acquisitions: A Review of Recent Empirical Studies. Advances in Mergers and Acquisitions, 13, 181-200. Retrieved from http://www.emeraldinsight.com/doi/full/10.1108/S1479-361X201400

Kaplan, A. (1964). The Conduct of Inquiry. New York, NY: Harper \& Row.

Kaplan, R. S., \& Norton, D. (1996). Using the Balanced Scorecard as a Strategic Management System. Harvard Business Review, 74(1), 75-85.

Kaufman Hall. (2015). Hospital Merger and Acquisition Activity. Retrieved from https://www.kaufmanhall.com/..../hospital-merger-and-acqusition-activity

Kim, J., \& Mahoney, T. J. (2005). Property Rights Theory, Transaction Cost Theory, and Agency Theory: An Organizatinal Economics Approach to Strategic Management. Managerial and Decision Economics, 26, 223-242.

Kirigia, J. M., Preker, A., Carrin, G., Mwikisa, C., \& Diarra-Nama, A. J. (2006). An Overview of Health Financing Patterns and the Way Forward in the WHO African Region. East African Medical Journal, 83(9), S1-S28. 
Klein, P. J., \& Shefanski, H. (1994). Empirical Research in Transacion Cost Economics: A Survey and Assessment. Working Paper, Hass School of Business, University of California, Business and Public Policy, Berkeley.

Klos, K. (2000). Assumption of Privatization of Regional Independent Public Healthcare Facilities in Malopolska. Krakow: Office of the Malopolskie Voivodeship Marshall.

Kombo, D. K., \& Tromp, P. L. (2009). Proposal and Thesis Writing: An Introduction. Nairobi, Kenya: Paulines Publications Africa, Don Bosco Printing Press.

Kothari, R. C., \& Garg, G. (2014). Research Methodology - Methods and Techniques (3rd ed.). New Delhi, India: New Age International (P) Ltd Publishers.

KPMG. (2011). The Seventh Wave of Merger and Acquisition. Retrieved from www.kpmg.com/za/en/..../transactions..../seventh-wave-of-m\&a.aspx

Krishnan, A. R., Joshi, S., \& Krishnan, H. (2004). The Influence of Mergers or Firm's Product Mix Strategies. Strategic Management Journal, 25, 587-611.

Kumar, R. (2014). Research Methodology: A Step-By-Step Guide for Beginners (4th ed.). London, England: SAGE Publications Ltd.

Lasker, R. D., \& Weiss, E. S. (2003). Creatin Partnerships Synergy: The Critical Role of Community Stakeholders. Journal of Health and Human Services Administration, 26(1), 119-139.

Lawrence, B. T., \& Shadnam. (2008). Institutional Theory. The International Encyclopaedia of Communication.

Levine, M. A., Stephan, F. D., Krehbiel, C. T., \& Berenson, L. M. (2013). Statistics for Managers Using Microsoft Excel. Upper Saddle River, NJ: Pearson Education Limited.

Libecap, G. D. (1989). Contracting for Property Rights. New York, NY: Cambridge University Press.

Majumdar, K. S. (1996). Assessing Comparative Efficiency of State-Owned, Mixed and Private Sectors in Indian Industry. Public Choice, 96, 1-24.

Makhija, M. (2003). Comparing the Resource-Based And Market-Based Views of the Firm: Empirical Evidence from Czech Privatization. Strategic Management Journal, 24, 433-451.

Martin, D., \& Dhalla, I. (2010). Privatizing Healthcare is Risk for All of Us. Retrieved from http://www.theglobeandmail.com/news/national/time-to-lead/privatizing-healthcare-is-risky-for-allof-us/article1 395420

Martins, R., Serra, R., Da Silva, F., Leite, A., Ferreira, P. M., \& Li, D. (2010). Transaction Cost Theory Influence in Strategy Research: A Review through A Billion Metric Study in Leading Journals. Global Advantage Center for Research in International Business and Strategy.

McCutchen, W. W., \& Swamidass, P. M. (2004). Motivations for Strategic Alliances in Pharmaceutical/Biotech Industry: Some New Findings. Journal of High Technology Management Research, 15, 197-214.

Megginson W, Nash, R., \& van Randenborgh, M. (1994). The Financial and Operating Performance of Newly Privatized Firms: An International Empirical Analysis. Journal of Finance, 49, 403-452.

Megginson, W. (2000). Privatization. Foreign Policy, 118, 14-27.

Megginson, W., \& Netter, J. (2001). From State to Market: A Survey of Empirical Studies on Privatization. Journal of Economic Literature, 39, 321-389.

Merton, K. R. (1967). On Theoretical Sociology. New York, NY: Free Press.

Mills, A. J., \& Ranson, M. K. (2001). The Design of Health System. International Public Heath - Diseases, Programs, Systems, and Policies. Gaithersburg, MD: Aspen Publishers.

Mohandas, B. (2016). Indian Healthcare Providers Look beyond Medical Tourism to a Promising African Market. Huffingtong Post. Retrieved from https://www.huffingtonpost.com/biju-mohandas/indian-healthcare-provide_b_12443178.html

Motis, J. (2007). Mergers and Acquisitions Motives. Tolouse School of Economics and University of Crete. Retrieved from https://www.soc.uoc.gr/wpa/docs/paper2motis.pdf

Muindi, S. (1992). Public Enterprise in Reform and Privatisation in Kenya. Retrieved from http://unpant.un.org/intradoc/group/public/documents/AAPAM/UHPANO28231.pdf 
Nadkarni, S. (2010). Healthcare System is an Industry. Management of the Sick Health System. Mumbai, India: Vora Medical Publication.

Nellis, J. (2005). Privatization in Africa: What Has Happened? What is to be Done? Center for Global Development.

Nemanich, L. A., \& Keller, R. T. (2007). Transformational Leadership in an Acquisition: A Field Study of Employees. The Leadership Quarterly, 18(1), 49-68.

Norman, G. (2010). Likert Scales, Levels of Management and the Laws of Statistics. Advanced Health Science Education Theory Practice, 15(5), 625-632.

North, D. C. (1984). Transaction Costs, Institutions, and Economic History. Journal of Institutional and Theoretical Economics, 140(1), 7-17. Retrieved from http://www.jstor.org/stable/40750667

Ochieng, M., \& Ahmed, H. A. (2014). The Effect of Privatization on the Financial Performance of Kenya Airways. International Journal of Business and Commerce, 3(5), 10-26.

Oliver, C. (1991). Strategic Responses to Institutional Processes. The Academy of Management Review, 16(1), 145-179.

Oliver, C. (1992). The Antecedents of Deinstitutionalization. Organization Studies, 13(4), 563-588.

Organization of African Unity. (2001). Abuja Declaration on HIV/AIDS, Tuberculosis and other Related Infectious Diseases. Organization of African Unity, Addis Ababa.

Parrino, J., College, B., \& Harris, R. (1999). Takeovers management replacement and post-acquisition operating performance: Some evidence from 1980S. Journal of Applied Corporate Finance, 2, 88-97.

Patel, P. B., Trivedi, K. N., Nayak, S. N., \& Patel, P. (2010). Health seeking behavior of peri-urban community of Chandkheda. National Journal of Community Medicine, 1(1), 35-36.

Pinto, L. M., \& Udwadia, Z. F. (2010). Private Patient Perceptions about a Public Program. What do Private Indian Tuberculosis Patients Really Feel about Directly Observed Treatment? BMC Public Health, 10, 356.

Pisano, G. P. (1991). The Governance of Innovation: Vertical Integration and Collaborative Arrangements in the Biotechnology Industry. Research Policy, 20, 237-249.

Porter, M. E. (1979). The Structure within Industries and Companies' Performance. Review of Economics and Statistics, 61, 214-227.

Porter, M. E. (1987). From Competitive Advantage to Corporate Strategy. Harvard Business Review, 65(3), 43-59.

Privatization Commission of Kenya. (2016). Retrieved from http://www.pc.go.ke/index.php?option=comcontent\&review=article\&id-134:background_information_on_state _corporations_reforms\&catid $=88 \&$ Itemid $=554$

Ramamurti, R. (2000). Multilevel Model of Privatizaton in Emerging Economies. The Academy of Management Review, 25(3), 525-500.

Ramasamy, B., Ong, D., \& Yeung, H. C. (2005). Firm Size, Ownership and Performance in the Malaysian Palm Oil Industry. Journal of Accounting And Finance, 1, 81-104.

Raut, K. N. (2012). Cause and Impact of Privatization in Nepal: A Theoretical Review. Banking Journal, 2(2), 1-22.

Ravenscraft, D., \& Scherer, F. (1987). Mergers, Sell-Offs, and Economic Efficiency. Washington, DC: The Brookings Institution.

Renyen, P., \& Decamara, D. (2004). The Secret of Successful of Mergers: Dispatches from the Front Lines. Journal of Business Strategy, 25(3), 10-14.

Reuters.com (2015). Kenya Seeks Bidders for Five State-owned Sugar Companies. Retrieved from http://af.reuters.com/article/kenyaNews/idAFL8N13T0AO20151204

Riley, J. (2012). The Main Motives behind Takeovers and Mergers. Retrieved from www.beta.tutor2u.net/..../blog/the-main-motives-behindtakeovers-and-mergers

Rindfleisch, A., \& Heide, B. J. (1997). Transaction Cost Analysis: Past, Present and Future Applications. Journal of Marketing, 61(4), 30-54.

Ross, S., Westerfield, R., \& Jaffe, J. (2010). Corporate Finance (9th ed.). New York, NY: McGraw-Hill/Irwin.

Rothman, A. (1988). Maxwell Hungers to Widen Philip Morris' Brands. Wall Street Journal, B10. 
Roy, W. G. (1997). Socializing Capital: The Rise of the Large Industrial Corporation in America. Princeton, NJ: Princeton University Press.

Ruester, S. (2010). Recent Development in Transaction Cost Economics. Retrieved from http://www.sophia-ruester.de

Ruppert, B. (2009). Post Acquisition Audit in 30 Days. Retrieved from https://www.sans.org/reading/auditing/post-acquisition-audit-30days-330

Sales, A. L., \& Mirvis, P. H. (1984). When Cultures Collide: Issues in Acquisition. (J. R. Kimberly, \& R. E. Quinn, Eds.) Homewood, IL: Dow Jones-Irvin.

Sambo, G. L., Kirigia, M. J., \& Orem, N. J. (2013). Health Financing in the African Region 2000 - 2009 Data Analysis. International Archives of Medicine. Retrieved from http://www.intarchmed.co/content/6/1/10

Sanda, M. A., \& Adjei-Benin, P. (2011). How is the Firm Dealing with Merger? A Study of Employee Satisfaction with the Change Process. Journal of Management and Strategy, 2(2), 28-37.

Scott, W. R. (2001). Institutions and Organizations (2nd ed.). Thousand Oaks, CA: Sage.

Scott, W. R. (2007). Institutions and Organizations: Ideas and Interest. Thousand Oaks, CA: Sage Publications.

Segal, I. S., \& Whinston, D. M. (2010). Property Rights. Retrieved from stanforduniversity>web>rights

Shah, U., \& Mohanty, R. (2010). Private Sector in Indian Healthcare Delivery: Consumer Perspective and Goverment Policies to Promote Private Sector. Information Management and Business Review, 1(2), 79-87.

Shan, W., \& Visudtibhan, K. (1990). Cooperative Strategy in Commercializing in Emerging Technology. European Journal of Operating Research, 47, 172 - 181.

Shanley, T. M., \& Correa, E. M. (1992). Agreement Between Top Management Teams and Expectations for Post-Acquisition Performance. Strategic Management Journal, 13, 245-266.

Shen, W., \& Lin, C. (2009). Firm Profitability, State Ownership, and Top Management Turnover at the Listed Firms in China: A Behavioral Perspective. Corporate Governance: An International Review, 17(4), 443-456.

Shleifer, A. (1998). State versus Private Ownership. Journal of Economic Perspective, 12, 133-150.

Shleifer, A., \& Vishny, R. W. (1997). A Survey of Corporate Governance. Journal of Finance, 52, 737-777.

Simam, R., \& Rotich, R. (2011). Textbook Selection and Approval in Kenya: Financial Impact on the Publisher.

Simon, H. A. (1957). Models of Man, Social and Rational. New York, NY: Wiley.

Sinha, K. (2012). Government Wants to Further Privatize Healthcare. The Times of India. Retrieved from http://timesofindia.indiatimes.com/India/Govt-wants-to-further-privatize-healthcare/articleshow1777446.coms

Siuda, K. K., \& Romaniuk, P. (2006). Privatization of Hospitals in Poland: Barriers and Opportunities. Central Europe Journal of Public Health, 14(1), 25-29.

Smith, C. P., \& Witter, N. S. (2004). Risk Pooling in Healthcare Financing: The Implications for Health System Performance and Development Network. The International Bank for Reconstruction and Develpment. The World Bank, Washington DC.

Smith, R. L. (2004). Entrepreneurial Finance (2 ed.). New York, NY: John Wiley \& Sons.

Smith, R., \& Sandler, L. (1988). Philip Morris Track Record in Acquisitions Draws Flak. Wall Street Journal, C1.

Sudarsanam, S. (2003). Creating Value From Mergers and Acquisitions: The Challenges. Financial Times.

Sudarsanam, S. (2005). Creating Value from Mergers and Acquisitions. Malaysia: Prentice Hall.

Sullivan, M. G., \& Artino, R. A. (2013). Analyzing and Intepreting Data from Likert-Type Scales. Journal of Graduate Medical Education, 5(4), 541-542.

Sutton, I. R., \& Staw, M. B. (1995). What Theory is Not. Administrative Science Quarterly, 40(3), 371-384.

The World Bank. (2012). Healthcare Expenditure Total (\% of GDP). Retrieved from http://www.worldbank.org/indicator/SHXPD

Thelen, K., \& Steinmo, S. (1992). Historical Institutionalism in Comparative Politics. (K. Thelen, S. Steinmo, \& F. Longstreth, Eds.) New York, NY: Cambridge University Press. 
Thoenig, C. J. (2007). Institutional Theories and Public Institutions: Traditions and Appropriateness. Retrieved from https://halshs.archives-ouvertes.fr/halshs-00139954

Thomas, L. (2016). An Investor's Plan to Transplant Private Healthcare in Africa. The New York Times.

Tiemann, O., \& Schreyögg, J. (2012). Changes in Hospital Efficiency after Privatization. Health Management Science, 15(4), 310-326.

Trautwein, F. (1990). Merger Motives and Merger Prescriptions. Strategic Management Journal, 11, 283-295.

Vickers, J., \& Yarrow, G. (1998). Privatization: An Economic Analysis. London and Massachussetts: The MIT Press.

Villa, S., \& Kane, N. (2013). Assessing the Impact of Privatizing Hospitals in Three American States: Implications for Universal Health Coverage. Value in Health, 16(1), 24-33.

Weiss, N. A. (2012). Elementary Statistics (8th ed.). Boston, MA: Pearson Education.

Wernerfelt, B. (1984). A Resource-Based View of the Firm. Strategic Management Journal, 5(2), 171-180.

Williamson, E. O. (1975). Markets and Hiearchies, Analysis and Anti-Trust Implications: A Study in Economics of International Organizations. New York, NY: Free Press.

Williamson, E. O. (1993). The Economic Analysis of Institutions and Organizations in General and with Respect to Country Studies. Working Paper, OECD, Economics.

Witter, S., Ensor, T., Towett, M., \& Thompson, R. (2000). Health Economics for Developing Countries: A Practical Guide. Basingstoke, England: Macmillan.

World Health Organization. (2000). The World Health Report 2000 - Health System: Improving Performance. World Health Organization, Geneva.

\section{Appendices}

Appendix 1. Graphic distribution of responses to demographic section

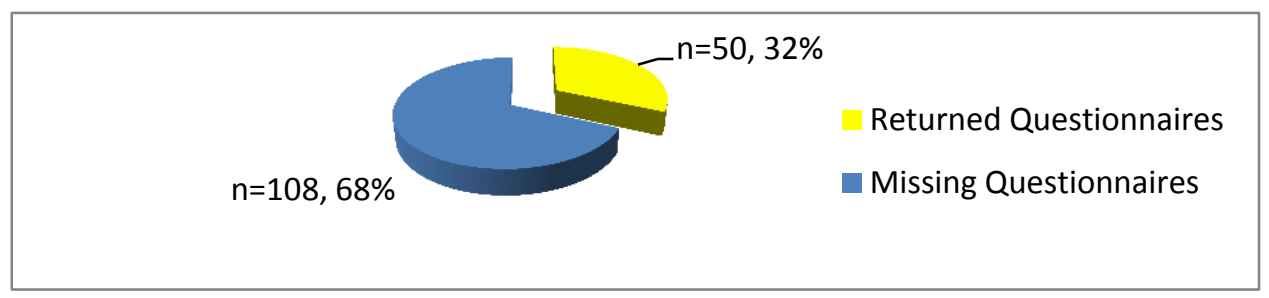

Figure 1. Response rate to self-administered questionnaire

Source: Author (2017)

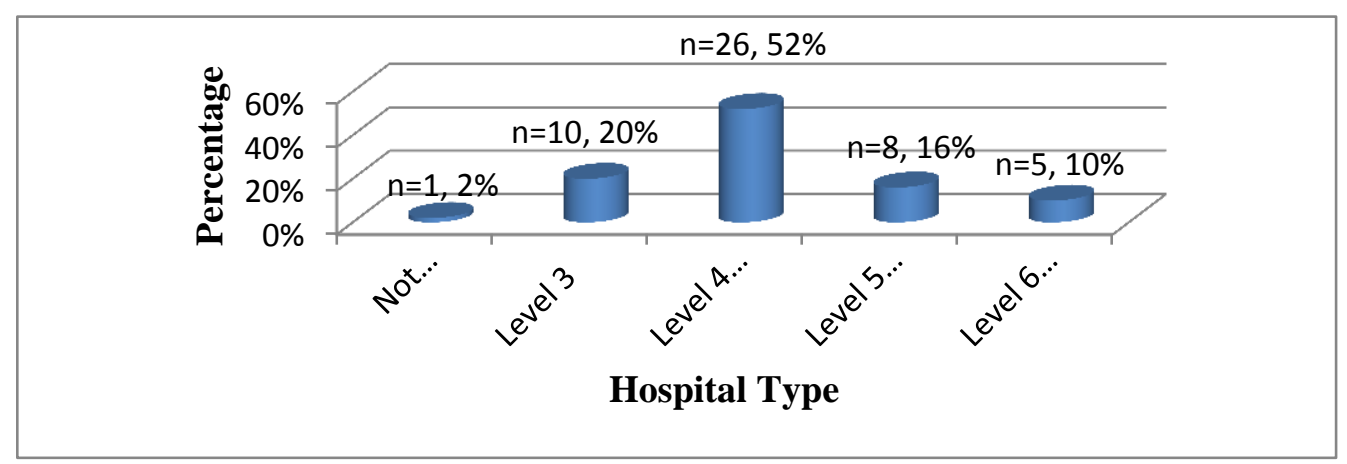

Figure 2. Type of hospital studied

Source: Author (2017) 


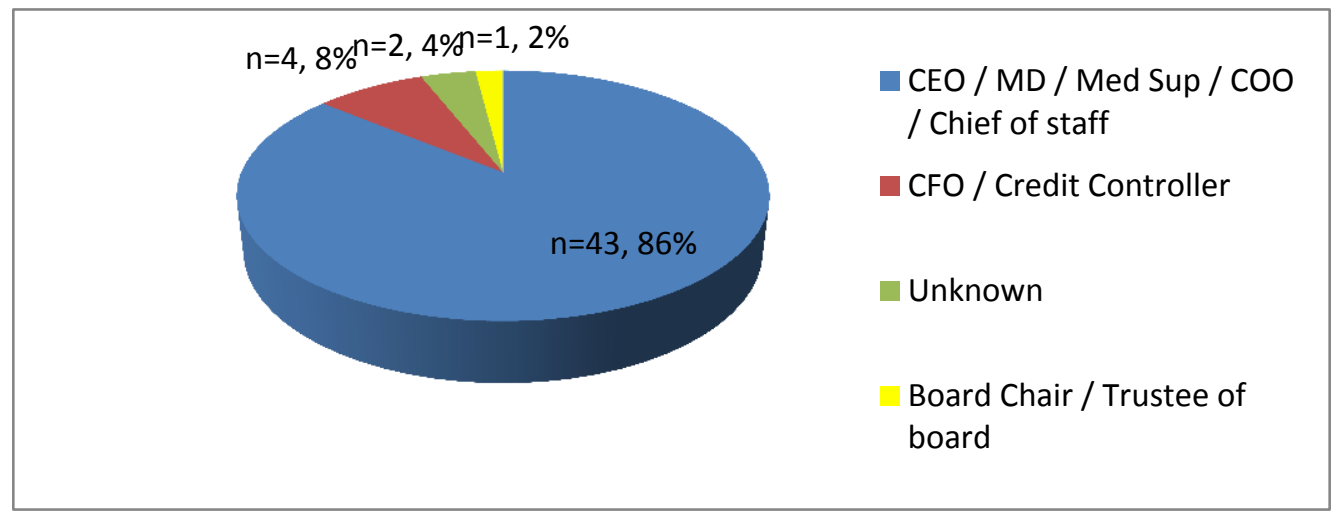

Figure 3. Position of respondents in hospital

Source: Author (2017)

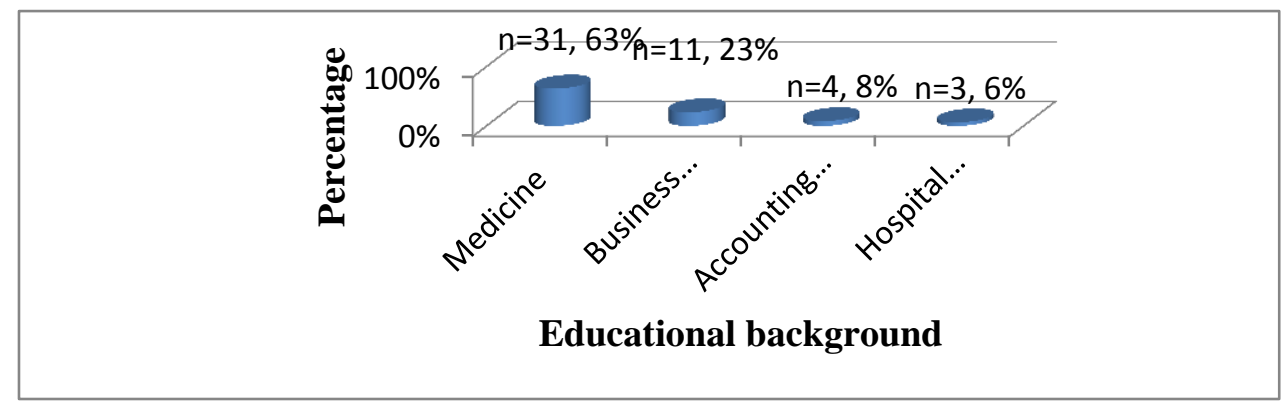

Figure 4. Education background

Source: Author (2017)

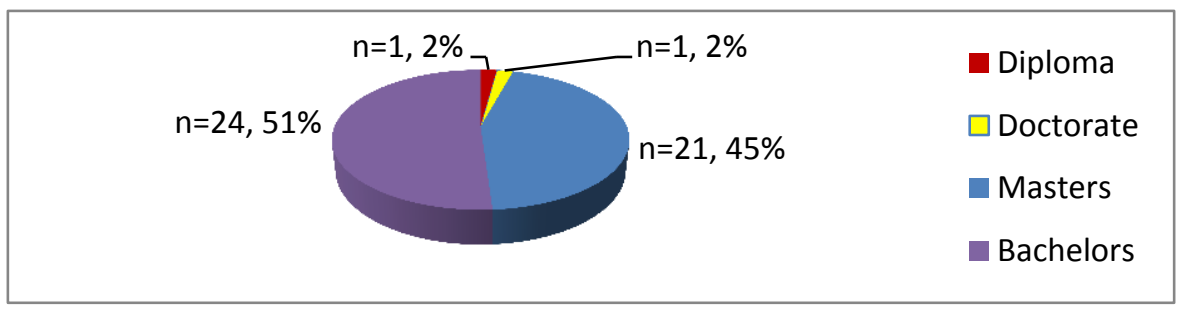

Figure 5. Level of education obtained

Source: Author (2017)

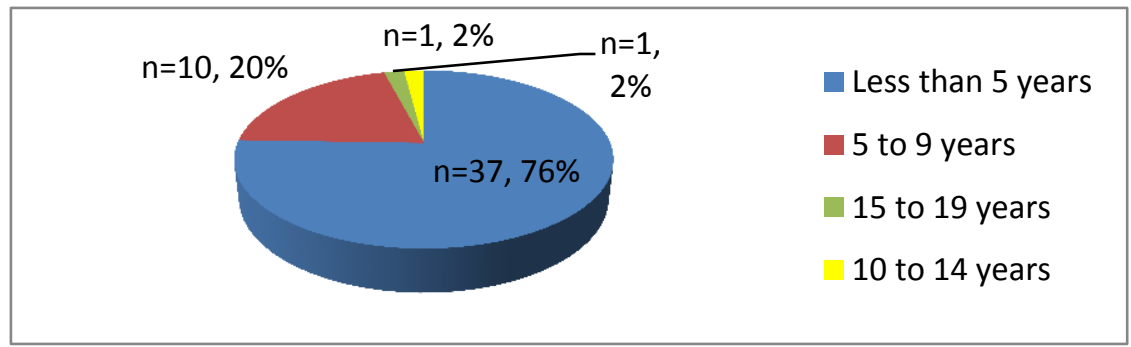

Figure 6. Length of service with the organization

Source: Author (2017) 


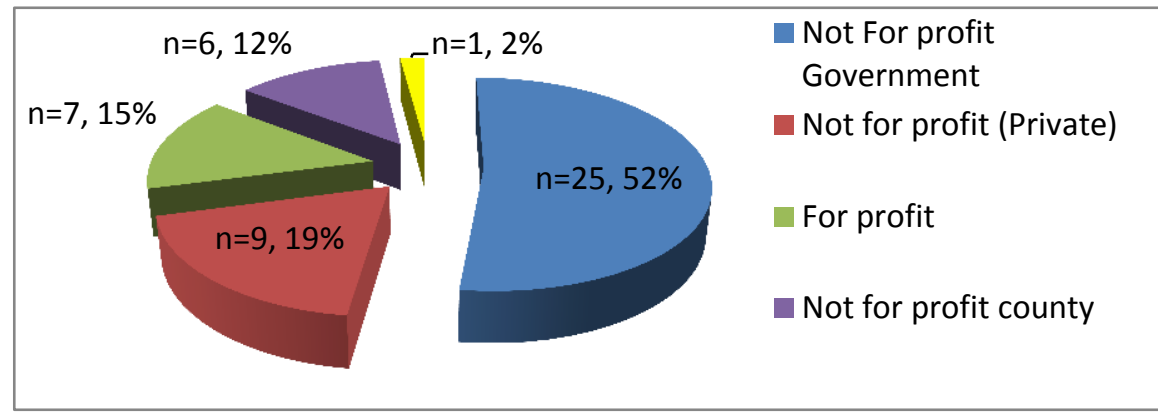

Figure 7. Legal form of hospitals

Source: Author (2017)

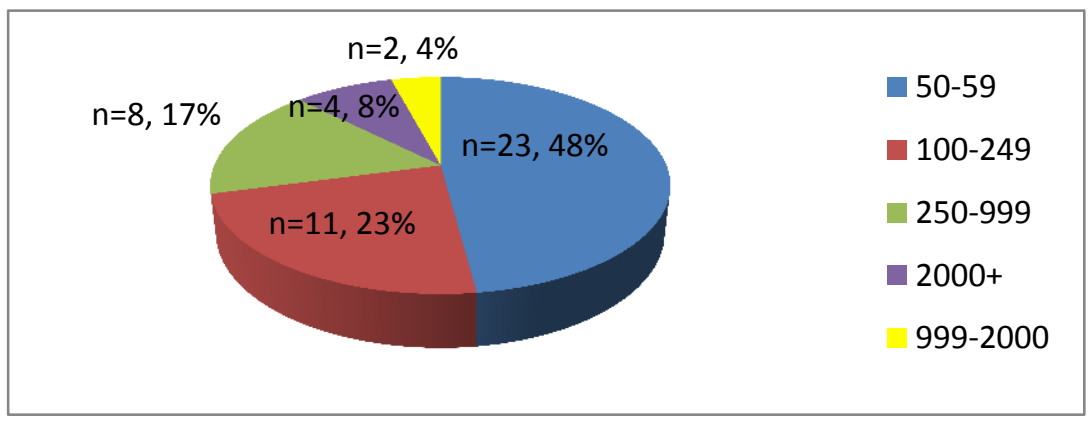

Figure 8. Staff Size of hospitals

Source: Author (2017)

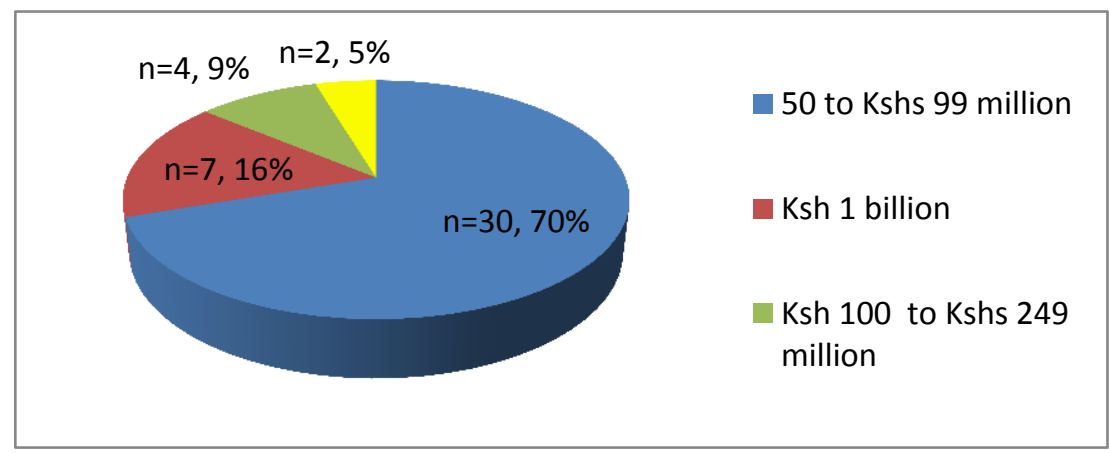

Figure 9. Net revenue of hospitals

Source: Author (2017)

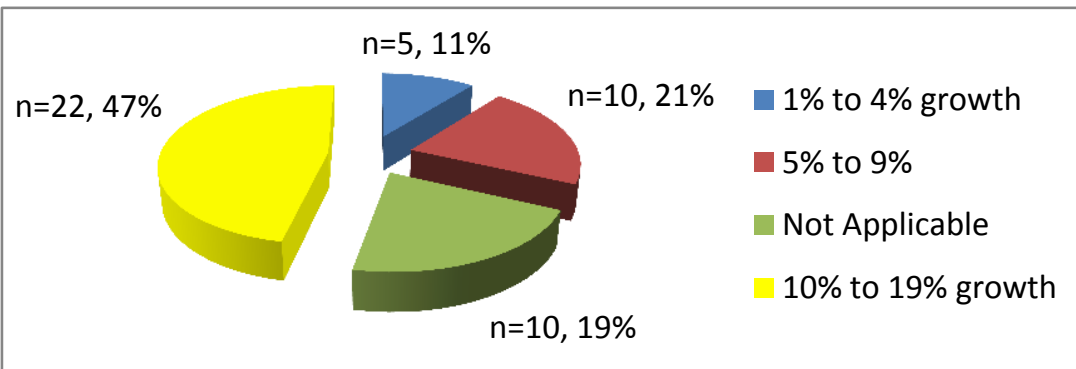

Figure 10. Hospital growth in revenue

Source: Author (2017) 


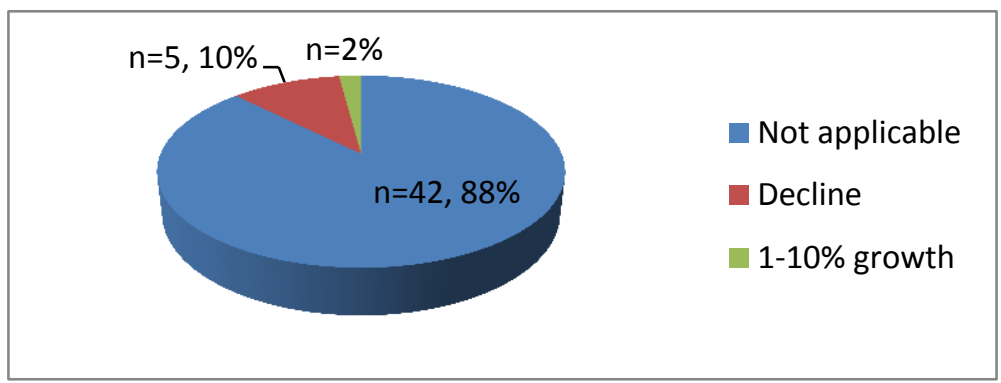

Figure 11. Hospital decline in revenue growth

Source: Author (2017)

Appendix 2. Descriptive findings of top leadership in descending order

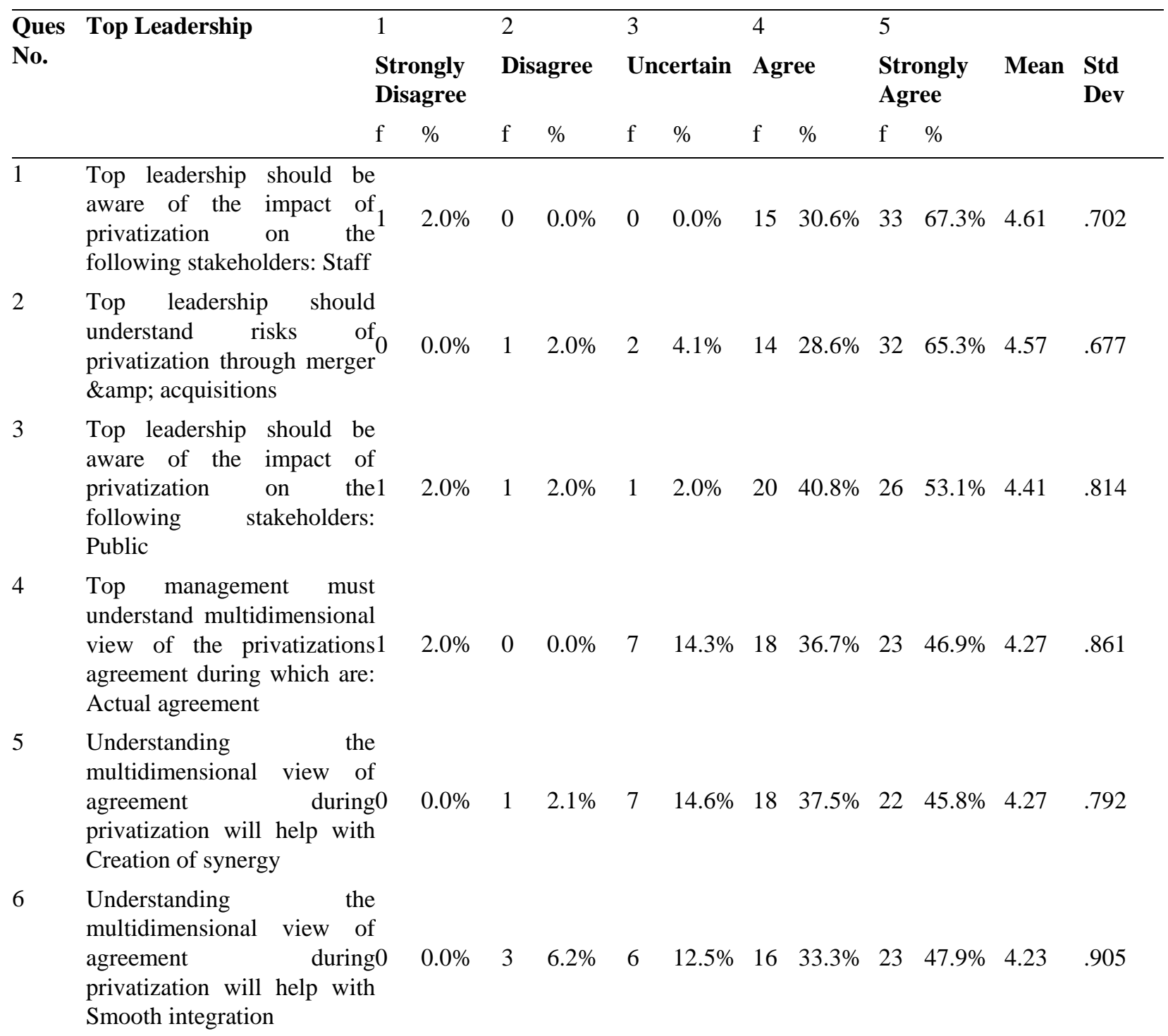


7 Top management must understand multidimensional view of the privatizations 1 agreement during which are:

$\begin{array}{lllllllllll}2.0 \% & 0 & 0.0 \% & 9 & 18.4 \% & 16 & 32.7 \% & 23 & 46.9 \% & 4.22 & .896\end{array}$ Accuracy of the agreement I believe $\begin{array}{lllllllllllll}\text { privatization/mergers } & 0 & 0.0 \% & 2 & 4.1 \% & 3 & 6.1 \% & 26 & 53.1 \% & 18 & 36.7 \% & 4.22 & .743\end{array}$ Revenue and Profitability

$9 \quad \mathrm{I}$

I believe

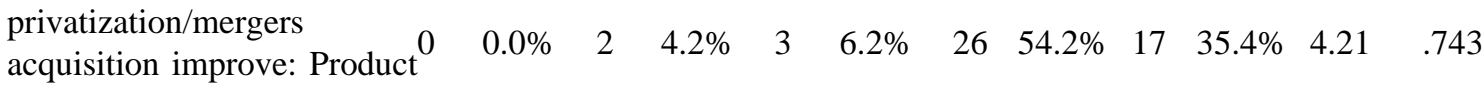
Mix

10 I believe

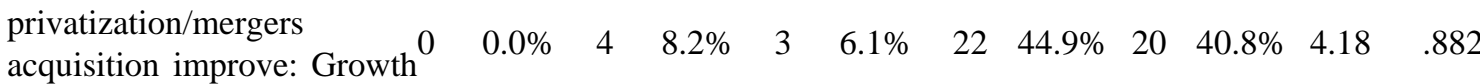
of services

11 Prior experience with privatization, merger \&amp; acquisition is beneficial to $\begin{array}{lllllllllll}0.0 \% & 2 & 4.1 \% & 7 & 14.3 \% & 21 & 42.9 \% & 19 & 38.8 \% & 4.16 & .825\end{array}$ top leadership

12 Resources of a firm including top leadership / entrepreneurship influence its value during privatization/merger and acquisition

13 The most important aspects of privatizations of public hospitals are :Leadership $2.1 \%$ structure

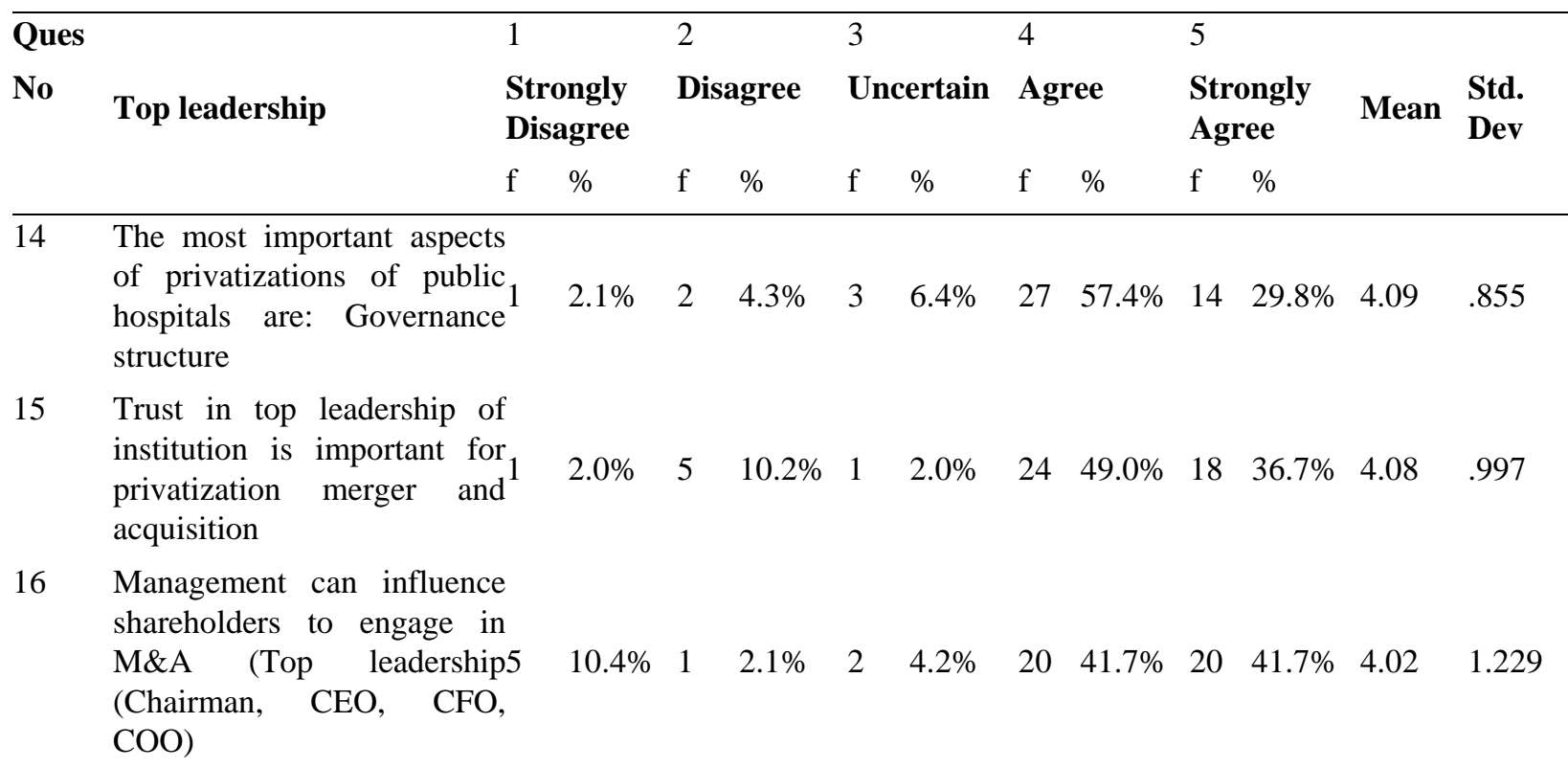


17 I believe privatization /

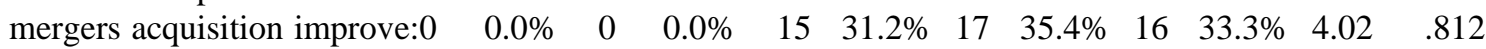
Politicians

18 Top management must understand multidimensional

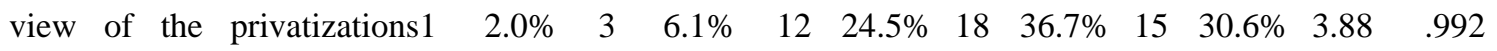
agreement during which are: Perceived agreement

19 The most important aspects of privatizations of public hospitals are: Government ${ }^{3}$ $\begin{array}{lllllllllll}6.4 \% & 2 & 4.3 \% & 5 & 10.6 \% & 26 & 55.3 \% & 11 & 23.4 \% & 3.85 & 1.042\end{array}$ role after privatization

20 Understanding the multidimensional view of agreement during0 privatization will help with Reduction complexity

21 The most important aspects of privatizations of public1 hospitals are: Type of buyer

$\begin{array}{lllllllllll}2.1 \% & 3 & 6.4 \% & 10 & 21.3 \% & 23 & 48.9 \% & 10 & 21.3 \% & 3.81 & .924\end{array}$

22 I believe privatization / mergers acquisition improve: 1 Public

$\begin{array}{lllllllllll}2.0 \% & 2 & 4.1 \% & 11 & 22.4 \% & 29 & 59.2 \% & 6 & 12.2 \% & 3.76 & .804\end{array}$

23 Privatization of public hospitals improves governance quality and 1
performance $\begin{array}{lllllllllll}2.0 \% & 7 & 14.3 \% & 7 & 14.3 \% & 25 & 51.0 \% & 9 & 18.4 \% & 3.69 & 1.004\end{array}$

24 Top leadership of public hospitals are not well incentivized to improve performance

$\begin{array}{lllllllllll}0.0 \% & 13 & 26.5 \% & 3 & 6.1 \% & 20 & 40.8 \% & 13 & 26.5 \% & 3.67 & 1.144\end{array}$

25 Top leadership should be aware of the impact of $\begin{array}{lllllllllllll}\text { privatization } & \text { on the } & 8.2 \% & 9 & 18.4 \% & 7 & 14.3 \% & 13 & 26.5 \% & 16 & 32.7 \% & 3.57 & 1.339\end{array}$ following stakeholders:

Politicians

26 Understanding the multidimensional view of agreement during1 privatization will help with Reduction of stress

27 Leadership of public hospitals are not well $2 \begin{array}{llllllllllll}2 & 4.1 \% & 14 & 28.6 \% & 1 & 2.0 \% & 20 & 40.8 \% & 12 & 24.5 \% & 3.53 & 1.260\end{array}$ equipped to compete in the competitive market

\begin{tabular}{|c|c|c|c|c|c|c|c|c|c|c|c|c|}
\hline \multirow{3}{*}{$\begin{array}{l}\text { Ques } \\
\text { No }\end{array}$} & \multirow{3}{*}{ Top leadership } & \multirow{2}{*}{$\begin{array}{l}1 \\
\text { Strongly } \\
\text { Disagree }\end{array}$} & \multirow{2}{*}{\multicolumn{2}{|c|}{$\begin{array}{l}2 \\
\text { Disagree }\end{array}$}} & \multirow{2}{*}{\multicolumn{2}{|c|}{$\begin{array}{l}3 \\
\text { Uncertain }\end{array}$}} & \multirow{2}{*}{\multicolumn{2}{|c|}{$\begin{array}{l}4 \\
\text { Agree }\end{array}$}} & \multicolumn{4}{|c|}{5} \\
\hline & & & & & & & & & & $\begin{array}{l}\text { ongly } \\
\text { ee }\end{array}$ & Mean & $\begin{array}{l}\text { Std. } \\
\text { Dev }\end{array}$ \\
\hline & & $\%$ & $\mathrm{f}$ & $\%$ & $\mathrm{f}$ & $\%$ & $\mathrm{f}$ & $\%$ & $f$ & $\%$ & & \\
\hline
\end{tabular}


$28 \quad$ Managers of public hospitals institution have vague goals

in comparison to their1

$\begin{array}{lllllllllll}2.1 \% & 16 & 34.0 \% & 5 & 10.6 \% & 16 & 34.0 \% & 9 & 19.1 \% & 3.34 & 1.203\end{array}$ counterpart in private hospital institutions

29 Replacement of top leadership team will impact $\begin{array}{llllllllllll}\text { effectiveness of privatization } 1 & 2.0 \% & 13 & 26.5 \% & 9 & 18.4 \% & 22 & 44.9 \% & 4 & 8.2 \% & 3.31 & 1.025\end{array}$ through merger and acquisition

30 Government will avoid bankruptcy of public hospital therefore management is not $4.3 \%-9$ $\begin{array}{llllllll}19.6 \% & 16 & 34.8 \% & 13 & 28.3 \% & 6 & 13.0 \% & 3.26\end{array}$ effective

31 Top leadership should be aware of the impact of privatization on the 5 following stakeholders: Media

32 Provision of healthcare services in Kenya must shift $\begin{array}{llllllllllll}\text { from more public sector15 } & 30.6 \% & 11 & 22.4 \% & 7 & 14.3 \% & 8 & 16.3 \% & 8 & 16.3 \% & 2.65 & 1.480\end{array}$ focus to more private sector focus

Source: Author (2017) 
Appendix 3. Chi-square test for gender and top leadership

\begin{tabular}{|c|c|c|c|c|}
\hline $\begin{array}{l}\text { Test of association between gender and top } \\
\text { leadership }\end{array}$ & Value & df & $\begin{array}{l}\text { Asymptotic } \\
\text { Significance } \\
\text { (2-sided) }\end{array}$ & $\begin{array}{l}\text { Percent r of } \\
\text { Expected counts } \\
<5\end{array}$ \\
\hline $\begin{array}{l}\text { Management can influence shareholders to engage } \\
\text { in M\&A (top leadership: Chairman, CEO, CFO, } \\
\text { COO) }\end{array}$ & $1.637^{\mathrm{a}}$ & 4 & .802 & $80.0 \%$ \\
\hline $\begin{array}{l}\text { Managers of public hospitals institution have } \\
\text { vague goals in comparison to their counterpart in } \\
\text { private hospital institutions. }\end{array}$ & $3.499^{\mathrm{a}}$ & 4 & .478 & $70.0 \%$ \\
\hline $\begin{array}{l}\text { The most important aspects of privatizations of } \\
\text { public hospitals are: Government role after } \\
\text { privatization }\end{array}$ & $9.311^{\mathrm{a}}$ & 4 & .054 & $70.0 \%$ \\
\hline $\begin{array}{l}\text { The most important aspects of privatizations of } \\
\text { public hospitals are: Type of buyer }\end{array}$ & $5.244^{\mathrm{a}}$ & 4 & .263 & $60.0 \%$ \\
\hline $\begin{array}{l}\text { The most important aspects of privatizations of } \\
\text { public hospitals are: Governance structure }\end{array}$ & $7.429^{\mathrm{a}}$ & 4 & .115 & $70.0 \%$ \\
\hline $\begin{array}{l}\text { The most important aspects of privatizations of } \\
\text { public hospitals are: Leadership structure }\end{array}$ & $7.090^{\mathrm{a}}$ & 4 & .131 & $70.0 \%$ \\
\hline $\begin{array}{l}\text { Top leadership should be aware of the impact of } \\
\text { privatization on the following stakeholders: Staff }\end{array}$ & $.723^{\mathrm{a}}$ & 2 & 697 & $50.0 \%$ \\
\hline $\begin{array}{l}\text { Top leadership should be aware of the impact of } \\
\text { privatization on the following stakeholders: } \\
\text { Politicians }\end{array}$ & $3.473^{\mathrm{a}}$ & 4 & .482 & $60.0 \%$ \\
\hline $\begin{array}{l}\text { Top leadership should be aware of the impact of } \\
\text { privatization on the following stakeholders: Media }\end{array}$ & $2.922^{\mathrm{a}}$ & 4 & .571 & $70.0 \%$ \\
\hline $\begin{array}{l}\text { Top leadership should be aware of the impact of } \\
\text { privatization on the following stakeholders: Public }\end{array}$ & $5.117^{\mathrm{a}}$ & 4 & .276 & $70.0 \%$ \\
\hline $\begin{array}{l}\text { Top management must understand } \\
\text { multidimensional view of the privatizations } \\
\text { agreement during which are: Perceived agreement }\end{array}$ & $4.423^{\mathrm{a}}$ & 4 & .352 & $70.0 \%$ \\
\hline $\begin{array}{l}\text { Top management must understand } \\
\text { multidimensional view of the privatizations } \\
\text { agreement during which are: Actual agreement }\end{array}$ & $1.881^{\mathrm{a}}$ & 3 & .597 & $50.0 \%$ \\
\hline $\begin{array}{l}\text { Top management must understand } \\
\text { multidimensional view of the privatizations } \\
\text { agreement during which are: Accuracy of the } \\
\text { agreement }\end{array}$ & $1.831^{\mathrm{a}}$ & 3 & .608 & $50.0 \%$ \\
\hline $\begin{array}{l}\text { Understanding the multidimensional view of } \\
\text { agreement during privatization will help with } \\
\text { smooth integration }\end{array}$ & $9.202^{\mathrm{a}}$ & 3 & $.027 *$ & $62.5 \%$ \\
\hline $\begin{array}{l}\text { Understanding the multidimensional view of } \\
\text { agreement during privatization will help with } \\
\text { creation of synergy }\end{array}$ & $2.847^{\mathrm{a}}$ & 3 & .416 & $62.5 \%$ \\
\hline $\begin{array}{l}\text { Understanding the multidimensional view of } \\
\text { agreement during privatization will help with }\end{array}$ & $2.231^{\mathrm{a}}$ & 3 & .526 & $62.5 \%$ \\
\hline
\end{tabular}


reduction complexity

Understanding the multidimensional view of agreement during privatization will help with reduction of stress

$\begin{array}{llllll}\text { Top leadership should understand risks of } & 1.651^{\text {a }} & 3 & .648 & 62.5 \%\end{array}$ privatization through merger and acquisitions

$\begin{array}{lllll}\text { Prior experience with privatization, merger and } & 3.894^{\mathrm{a}} & 3 & .273 & 75.0 \%\end{array}$ acquisition is beneficial to top leadership

\begin{tabular}{|c|c|c|c|c|}
\hline $\begin{array}{l}\text { Test of association between gender and top } \\
\text { leadership }\end{array}$ & Value & df & $\begin{array}{l}\text { Asymptotic } \\
\text { Significance } \\
\text { (2-sided) }\end{array}$ & $\begin{array}{l}\text { Percent } \\
\text { Expected counts } \\
<5\end{array}$ \\
\hline $\begin{array}{l}\text { Replacement of top leadership team will impact } \\
\text { effectiveness of privatization through merger and } \\
\text { acquisition }\end{array}$ & $3.700^{\mathrm{a}}$ & 4 & .448 & $60.0 \%$ \\
\hline $\begin{array}{l}\text { Privatization of public hospitals improves } \\
\text { governance quality and performance }\end{array}$ & $9.054^{\mathrm{a}}$ & 4 & .060 & $70.0 \%$ \\
\hline $\begin{array}{l}\text { Top leadership of public hospitals are not well } \\
\text { incentivized to improve performance }\end{array}$ & $5.364^{\mathrm{a}}$ & 3 & .147 & $62.5 \%$ \\
\hline $\begin{array}{l}\text { Leadership of public hospitals are not well } \\
\text { equipped to compete in the competitive market }\end{array}$ & $11.532^{\mathrm{a}}$ & 4 & $.021 *$ & $70.0 \%$ \\
\hline $\begin{array}{l}\text { Resources of a firm including top leadership / } \\
\text { entrepreneurship influence its value during } \\
\text { privatization / merger and acquisition }\end{array}$ & $11.420^{\mathrm{a}}$ & 4 & $.022 *$ & $70.0 \%$ \\
\hline $\begin{array}{l}\text { Trust in top leadership of institution is important } \\
\text { for privatization merger and acquisition. }\end{array}$ & $7.805^{\mathrm{a}}$ & 4 & .099 & $70.0 \%$ \\
\hline
\end{tabular}

*indicates where p-value is significant at $95 \%$ confidence level

Source: Author (2017) 